\title{
Applications of Biopolymers for Drugs and Probiotics Delivery
}

\author{
Roxana Gheorghita ${ }^{1,2}$, Liliana Anchidin-Norocel ${ }^{1}\left(\mathbb{0}\right.$, Roxana Filip $^{3}$, Mihai Dimian ${ }^{2,4}$ and Mihai Covasa ${ }^{1,5, *}$ \\ 1 Department of Health and Human Development, Stefan cel Mare University of Suceava, \\ 720229 Suceava, Romania; roxana.puscaselu@usm.ro (R.G.); liliana.norocel@usm.ro (L.A.-N.) \\ 2 Integrated Center for Research, Development and Innovation in Advanced Materials, Nanotechnologies, and \\ Distributed Systems for Fabrication and Control, Stefan cel Mare University of Suceava, \\ 720229 Suceava, Romania; dimian@usm.ro \\ 3 Hipocrat Clinical Laboratory, 720003 Suceava, Romania; roxana.filip@usm.ro \\ 4 Department of Computers, Electronics and Automation, Stefan cel Mare University of Suceava, \\ 720229 Suceava, Romania \\ 5 Department of Basic Medical Sciences, College of Osteopathic Medicine, \\ Western University of Health Sciences, Pomona, CA 91766, USA \\ * Correspondence: mcovasa@westernu.edu
}

check for updates

Citation: Gheorghita, R.; Anchidin-Norocel, L.; Filip, R.; Dimian, M.; Covasa, M. Applications of Biopolymers for Drugs and Probiotics Delivery. Polymers 2021, 13 2729. https://doi.org/10.3390/ polym13162729

Academic Editors: José Miguel Ferri, Vicent Fombuena Borràs and Miguel Fernando Aldás Carrasco

Received: 30 June 2021

Accepted: 11 August 2021

Published: 15 August 2021

Publisher's Note: MDPI stays neutral with regard to jurisdictional claims in published maps and institutional affiliations.

Copyright: (c) 2021 by the authors. Licensee MDPI, Basel, Switzerland. This article is an open access article distributed under the terms and conditions of the Creative Commons Attribution (CC BY) license (https:/ creativecommons.org/licenses/by/ $4.0 /)$

\begin{abstract}
Research regarding the use of biopolymers has been of great interest to scientists, the medical community, and the industry especially in recent years. Initially used for food applications, the special properties extended their use to the pharmaceutical and medical industries. The practical applications of natural drug encapsulation materials have emerged as a result of the benefits of the use of biopolymers as edible coatings and films in the food industry. This review highlights the use of polysaccharides in the pharmaceutical industries and as encapsulation materials for controlled drug delivery systems including probiotics, focusing on their development, various applications, and benefits. The paper provides evidence in support of research studying the use of biopolymers in the development of new drug delivery systems, explores the challenges and limitations in integrating polymer-derived materials with product delivery optimization, and examines the host biological/metabolic parameters that can be used in the development of new applications.
\end{abstract}

Keywords: drug; controlled release; polysaccharide; probiotics

\section{Introduction}

Biopolymers are generated by living organisms [1-5] and are defined as biologically degradable polymers [6]. They represent possible materials for the replacement of synthetic plastics due to an increased interest in developing environmental sustainability [7]. Biopolymers have a structural backbone with carbon, oxygen, and nitrogen atoms which makes them easily biodegradable. Biodegradation breaks them down into carbon dioxide, water, humic matter (organic macromolecular material), biomass, and other natural substances; thus, these materials are naturally recycled through biological processes [3].

A classification system based on their origin, synthesis and processing of different biodegradable polymers [8-12] is presented in Figure 1 in the form of a social network analysis. It divides the biopolymers in four major categories: extracted from biomass products (agrobiopolymers), from microorganisms, and from biotechnological and petrochemical products. Biopolymers from biomass products have diverse compounds such as polysaccharides (starches, celluloses, alginates, pectins, gums, and chitosan) [13]; proteins of animal origin (whey, collagen, and gelatin); proteins of vegetal origin (zein, soya, and wheat gluten) [14,15]; and lipids (bees wax, carnauba wax, and free fatty acids) [16,17]. Most biopolymers can be extracted from natural sources such as plants, animals, and microorganisms including algae and agro-wastes [18]. Agro-sources of biopolymers include bananas, maize, potatoes, tapioca, yams, rice, corn, wheat, cotton, sorghum, and barley $[19,20]$, while animal sources are derived from cattle, pigs, and other products. Agrowaste-based sources include apple pomace [21], tomato pomace, pineapple [22], orange 
and lemon peels, wheat straw, rice husks [23,24], paper wastes, crops, wood, and green wastes, while the marine sources are sponges [25], corals, lobsters, fishes, and shrimps [26]. Biomaterials manufactured from these products are described as stretchy, soft, and gel-like, with many characteristics of both solids and fluids. It is known that biopolymers can be smart and flexible materials even in living organisms [6] because they have a structure that is constantly manipulated either in response to environmental changes or by enzymes throughout different stages of the organism's lifecycle [27].

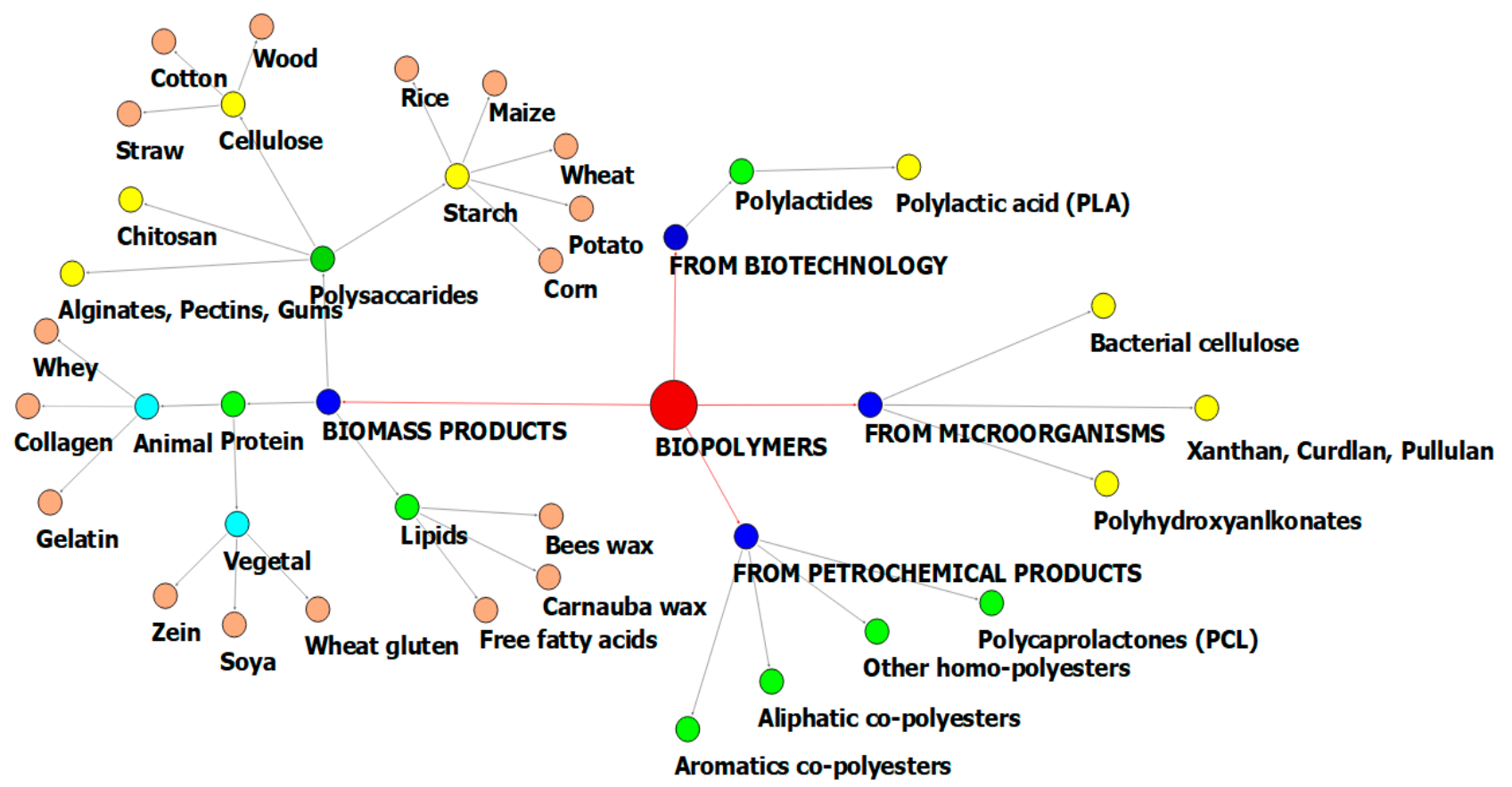

Figure 1. A social network graphical illustration of biopolymers classification.

The biopolymer composites can be prepared by several methods such as extrusion, electrospinning, grafting, different types of molding [28], solvent casting, melt blending, intercalation, filament winding, phase separation [29], laser printing, and film stacking [5].

Currently, the manufactured design and optimization of biopolymers through mathematical models are very advantageous because they improve their physical, chemical, electrical, and mechanical properties in order to increase resistance in humid, warm, or cold storage conditions and for applications that require specific features [30].

Although significant work has been done on the use of a wide range of biopolymers, most of them have been based on polysaccharides due to their improved properties compared to other categories such as proteins or lipids. Thus, this review focuses on the ability of biopolymers to be used successfully in the pharmaceutical industry as encapsulating agents, particularly for delivery of drugs and probiotics. Specifically, the paper describes the use of alginate, chitosan, agar, starch, and cellulose by focusing on the properties and characteristics that make them suitable candidates for product delivery, offering advantages over the chemically derived polymers. The following will also be presented: the development of encapsulated substances based on biopolymers; challenges and limitations such as the encapsulation process, shelf life, controlled release of embedded drugs, protection, and viability of live strains; and the rate of release at different $\mathrm{pH}$ mediums of the gastrointestinal fluids.

\section{Biopolymers vs. Conventional Synthetic Materials}

Several studies have been conducted concerning the utilization of biopolymers with the aim of developing sustainable packaging materials. Although significant improve- 
ments have been made, there is still considerable debate over economic considerations, environmental concerns, and product packaging performance [31].

Living organisms produce a variety of polymers as a significant part of their morphological, cellular, and dry matter. These biopolymers play vital roles in the life cycle of organisms including the preservation and expression of genetic information, catalysis of reaction [32], energy or other nutrients, sensing of abiotic and biotic factors, protecting against the attack of other cells, storage of carbon, and negotiation of the adhesion to the surface of other organisms [4].

Biopolymers present important features such as biodegradability [33,34], biocompatibility [35], sustainability [36], bioresorbability [37], flexibility [38], antibacterial activity [6], renewability [39], and stability [2]. They are also less toxic [40], non-immunogenic [41], non-carcinogenic, non-thrombogenic, carbon neutral, and have the advantage of easy extraction [42]. These properties are directly influenced by parameters such as the type of material used as the structural matrix (charge distribution, molecular mass, and conformation), film developing conditions (concentration, $\mathrm{pH}$, solvent, temperature, etc.) and category and concentration of additives (antimicrobials, crosslinking agents, plasticizers, antioxidants, etc.) [43].

Until recently, conventional synthetic materials have become part of most materials in our lives, including those present in beverages and food, clothes, daily used instruments, and baby-toys, and even in biomedical applications such as surgical equipment, drug delivery systems, and cosmetic personal care materials. Some studies have associated these materials with potential adverse health problems, particularly in pregnant women and newborn infants. To this end, hormonally active agents are a group of polymeric chemicals that have been associated with critical health issues such as cancerous tumors, congenital disabilities, and other disorders [40]. Furthermore, people have become more aware of the effects of chemically derived compounds and are more cautious in their use of conventional synthetic materials due to their effects on health and the environment. Today's consumers are more informed and sophisticated in their preferences and choices, increasingly looking for natural and vegan alternate products with high biocompatibility and low environmental implications. Furthermore, increasing efforts and research on the management of plastic waste on Earth are aimed towards finding eco-friendly alternatives to plastics [5]. Such eco-friendly alternatives can be represented by biopolymers, which are disposed in the environment and easily degradable through the enzymatic actions of microorganisms [44].

Compared with conventional synthetic materials that have a simpler and more random structure, these biopolymers are complex molecular assemblies that adopt defined and precise 3D configuration and structures [45]. Based on the composition and chemical structure of biopolymers, they are almost identical to the macromolecules of the native extracellular environment [46]. Many characteristics differentiate between the two types of materials, which are summarized in Table 1. Biopolymers have multiple advantages over conventional plastics due to their low/no toxicity, biodegradability, sustainability, biocompatibility, and extreme hydrophilicity. Furthermore, their morphology and chemical modifications can have a significant impact on their rate of biodegradation [47], an important feature in the development of new applications for food, biomedical, and pharmaceutical industries. Conversely, synthetic materials have a low cost and high thermal and mechanical properties that make them more usable than biopolymers.

Some applications of biopolymers have used mixtures with synthetic materials (such as polyethylene and polyvinyl alcohol), plasticizers (sorbitol and glycerin), nitrogenous bases, and others, thus obtaining a partially biodegradable material [7]. 
Table 1. Characteristics of biopolymers vs. synthetic polymers.

\begin{tabular}{|c|c|c|c|}
\hline Characteristic of Materials & Biopolymers & Synthetic Polymers & References \\
\hline Main source & Agro-resources & Petroleum and gas & [48] \\
\hline Biodegradability/environmentally friendly & YES & $\mathrm{NO} /$ slow & {$[49,50]$} \\
\hline Structure & Well defined & Stochastic & [48] \\
\hline Chemical backbone structure & Carbon, oxygen, and nitrogen & Mostly carbon & [48] \\
\hline Dispersity & Unity & $>1$ & [51] \\
\hline Physicochemical resistance & Low & High & [52] \\
\hline Toxicity & Low & High & [41] \\
\hline Thermal stability & Low & High & [52] \\
\hline Mechanical properties & Low & High & [53] \\
\hline Sustainability & High & Low & [52] \\
\hline Availability & High & Decreasing & [52] \\
\hline Cost & High (depends on the type) & Low & [54] \\
\hline
\end{tabular}

Although biopolymers have many advantages, there are a number of limitations in their processing, starting from the extraction and all the way up to the final product. First, being a completely natural product, biopolymers' final properties depend largely on the raw material. This can vary greatly due to the origin, climatic conditions, location, harvesting, and processing. Therefore, the world production of biopolymers cannot always maintain the same sustainability. To date, no universal acceptable procedures have been developed for the collection and manufacturing of biopolymer powders from vegetable materials. This is important both for the safety as well as the quality and performance of the final product. Second, because the production of biopolymers is still in its infancy, the production costs are quite high [55]. However, the elimination of recycling and waste taxes through world legislation mitigates some of the high costs. Third, the production of biopolymers necessitates special equipment other than those currently used. The development of such equipment and protocols requires time, additional costs, and trained staff. However, given that biopolymer processing technology is relatively easy and accessible, some existing equipment has been adapted for this purpose, thus reducing the costs [56]. Finally, the lower performance of biopolymers compared to conventional materials may limit their use, although continuous research advances in the technology and material combinations show great improvements in their characteristics that are comparable to conventional materials currently used [57].

\section{Applications of Biopolymers}

Recent research demonstrates the potential applications of biopolymers as materials for manufacturing medical devices [58]. The most suitable characteristics for suggesting these biomaterials are molecular weight, lubricity, material chemistry, water absorption degradation, shape and structure, solubility [59], hydrophilicity/hydrophobicity [60], erosion mechanism [61], and surface energy [62]. Besides these, other applications of biopolymers, such as those presented in Figure 2, are found in industries such as pharmaceutical preparations with encapsulation; food (edible film packaging and emulsifier) [63]; agriculture, which includes sustainable activities, methods for water recovery, and materials used as soil conditioner; the cosmetics industry (especially hydrogels) [64]; and water treatment substances, biosensors, and even data storage elements [1]. In these industries, polysaccharide-based materials have been developed under different forms such as films, membranes, fibers, hydrogels, food casing [65], sponges, and air gels [66]. 
Controlled drug delivery

Microcapsules

Micro/Nano Sphere

Hydrogel

Liposome

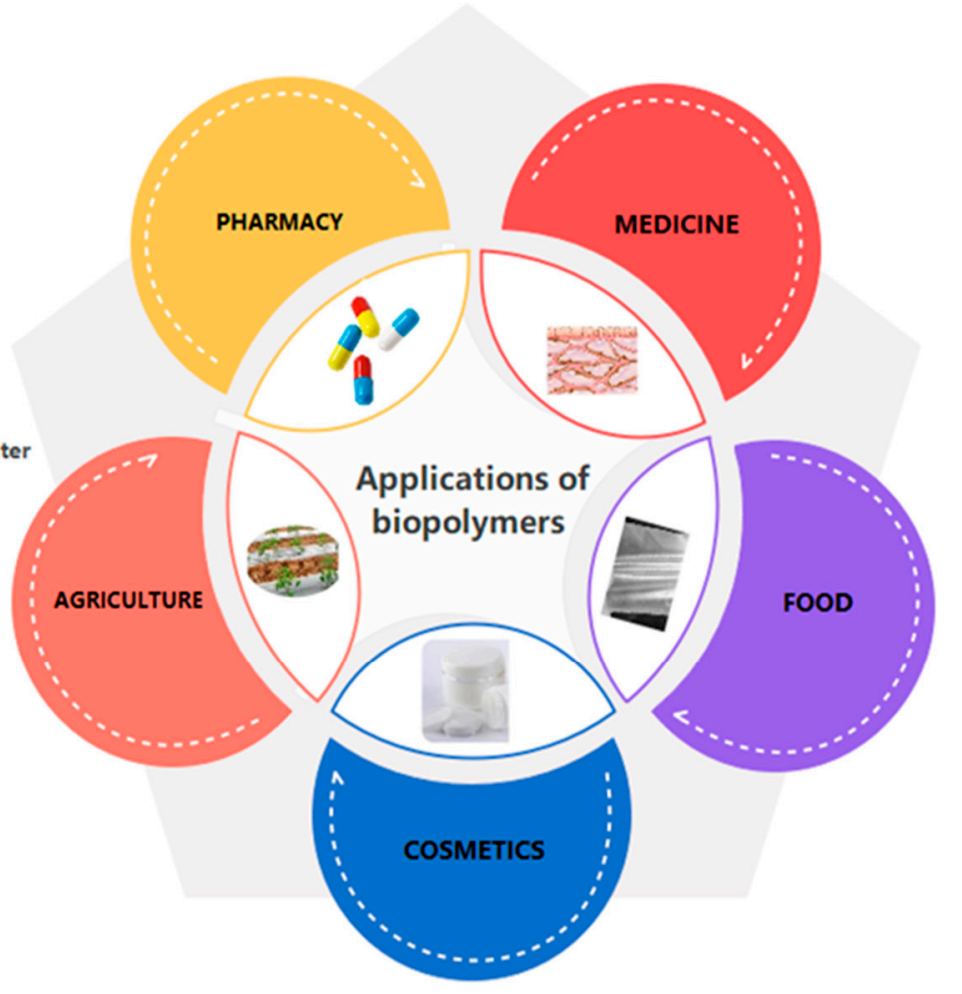

Hydrogels in cosmetics

Oral care

Skin care

Hair care

Mucous membrane care
Sustenable agro-practices, water

Biosorbents

Superabsorbents

Figure 2. Applications of biopolymers.

Packaging in the bio-medical industry is a method that allows for the closure of a pharmaceutical product from its fabrication to its end use. In pharmaceutical packaging, biopolymers are used to protect pills, nutraceuticals, drugs, surgical devices, powders, and liquids [63]. Pharmaceutical packaging has an impact on the isolation and ensures the safety, identity, and convenience of using the products. Packaging should be compatible with the patient's condition, be free of adverse effects on his/her health, and be environmentally safe [64].

As mentioned above, biopolymers can be also used in the preparation of edible packaging films for food products [65]. These films made from biomaterials can be ingested with the food because they are prepared from polysaccharides and proteins. Edible films have received special attention in the last years because of their alternative potential to replace synthetic materials, which could minimize packaging waste and reduce environmental pollution [66]. As a food packaging material, it can also improve the antimicrobial effect of packaging [67], shelf-life heat resistance, flexibility, mechanical strength, and barrier properties [68]. Edible films/coatings are currently used in a variety of other applications including collagen casings for sausages, chocolate coatings for fruits, and coatings for chocolates and other items [69]. Furthermore, biopolymers are used as emulsifiers and as both thickening and moisture-retaining agents in the food industry with the goal of improving the stability and physicochemical properties of food emulsions [70,71]. Finally, biopolymers have been extensively used in the delivery of bioactive compounds such as probiotics that are susceptible to degradation during preparation, storage, or under the adverse environmental conditions of the human gut. Similarly, they have been used for applications in the pharmaceutical industries as a delivery agent to improve drug stability and bioavailability. In the following sections, we will discuss the applications of biopolymers in drugs and probiotics delivery.

\subsection{Biopolymers in the Pharmaceutical Industry}

Due to their special properties, biopolymers have slowly begun to replace conventional materials. Whereas in the beginning they were mainly used in the food industry, their 
application in other related industries took place relatively quickly. In the pharmaceutical industry, they were initially used for the same purpose as in the food industry, which is as thickening and emulsifying agents, host molecules, bulking agents, or fibers. In addition, their use in cosmetics has increased substantially. According to existing data, it is estimated that the world biopolymer market will reach approximately USD 10 billion by the end of 2021, an increase by approximately 17\% between 2017 and 2021. The largest market segment is owned by Western Europe with approximately $41.5 \%$ of the global market [72]. In biomedicine, polymers have been used successfully both experimentally and in in vivo applications, wound dressing, tissue engineering, drug delivery, or in medical devices such as electronics, sensors, and batteries. Furthermore, due to their physical, thermal, mechanical, and optical properties, biopolymers are ideal materials widely used for food and pharmaceutical applications [5] (Figure 3).

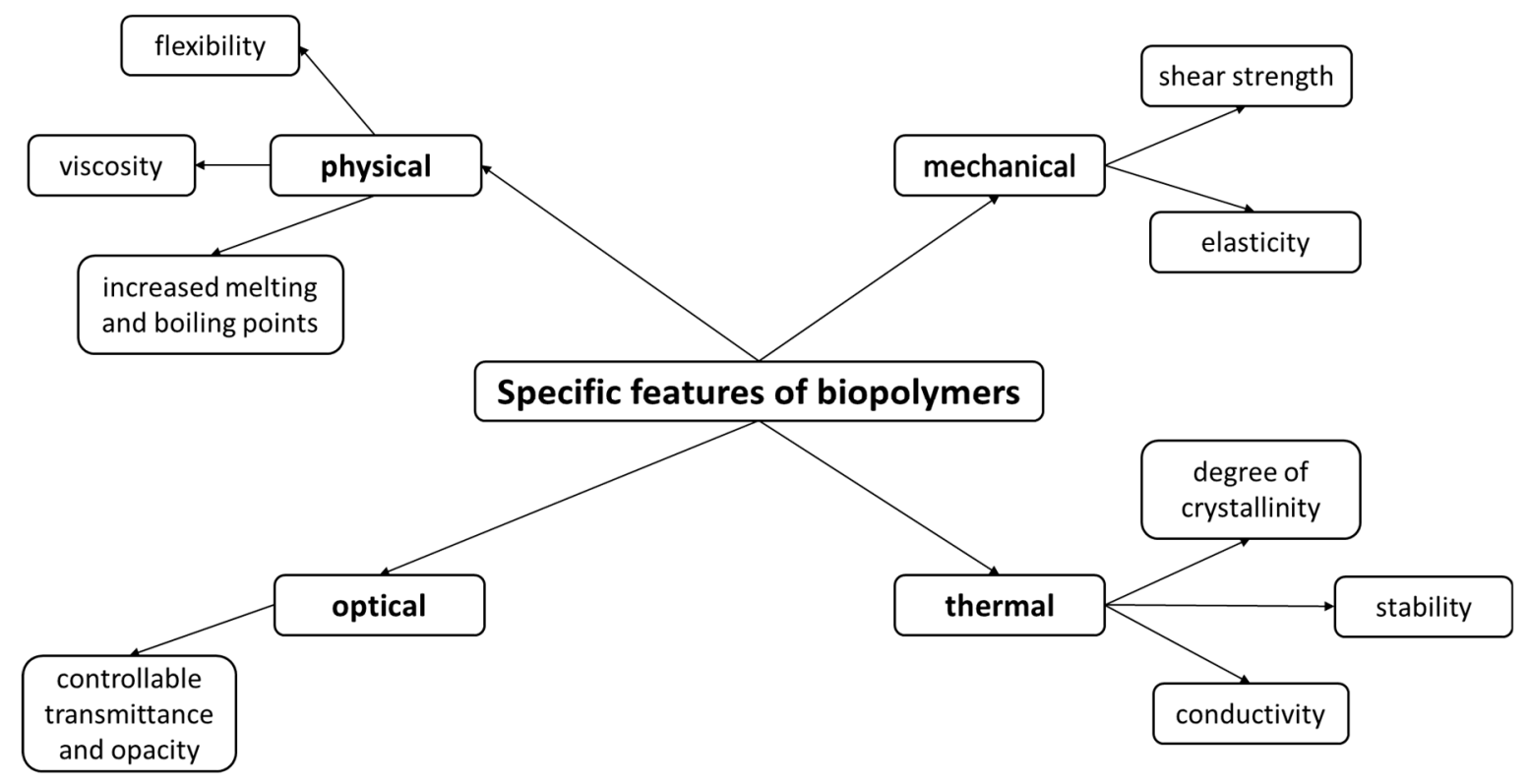

Figure 3. Specific features of biopolymers.

The composition and matrix of biopolymers can be manipulated in order to obtain the appropriate functional properties such as microstructure, permeability, and chargeability that are dependent on the internal structure of the polymer. Electrical characteristics influence the bonding of particles in the biopolymer matrix and their capacity to aggregate. The biopolymer fractions that prevent aggregation are the ones with a high electrical charge [58]. Based on these properties, biopolymers are used successfully to obtain nanoparticles, nanoemulsions, nanogels, or hydrogels with applications in the biomedical industry as carrier systems. Among them, polysaccharides are the most widely used category of biopolymers, either individually or in mixtures with other biopolymers to replace the synthetic materials or exist in addition to them.

\subsubsection{Biopolymers for Controlled Drug Release}

Encapsulation involves the protection of living cells from destruction by entrapment in biopolymer membranes and it is applied in micro and macrocapsules [73]. It is the procedure by which one or more materials, representing the active part or core material, is embedded or coated with another material or system, which is actually a mantle, shell, carrier, or encapsulant [74] (Figure 4). 


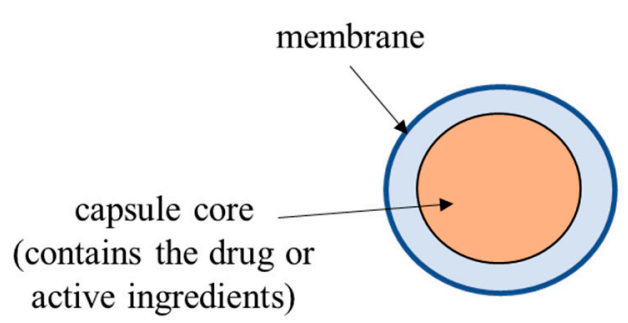

Microcapsule

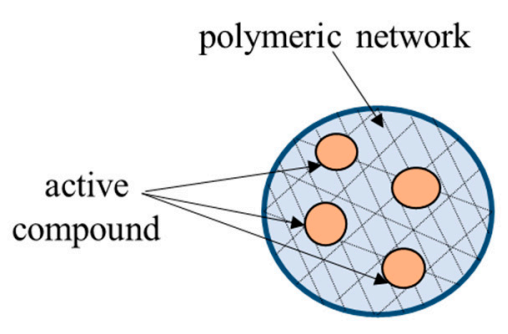

Microsphere

Figure 4. Graphical representation of drug encapsulation (adapted from Madene et al. [74] with permission from the publisher).

A specific feature of macrocapsules is the relatively large difference between the surface area and the volume. Thus, it is necessary to use a large number of nutrients to obtain an appropriate diffusion gradient for the entry of nutrients. This aspect overlaps with the necessary nutrition for the cells. In macrocapsules, living cells are entrapped in large diffusion chambers formed as flat sheets, hollow fibers, and disks with semi-permeable properties [75]. Macrocapsules can be used as intra or extra-vascular devices [76]. In intravascular devices, cells are connected to the bloodstream as a shunt, oriented outside the artificial capillaries. They are found in the vicinity of blood circulation, assisting with the rapid transfer of therapeutic and nutritional substances such as oxygen. The biggest disadvantage is the potential for developing thrombosis. Therefore, research is moving towards their use as extravascular devices with cells entrapped within semi-permeable diffusion chambers and placed transdermally or in the peritoneal cavity without the need for direct circulatory access. This involves a minor surgery and permits a quick and easy substitution in case of graft failure or when the transplant has to be replaced for other reasons [73]. Microcapsules allow for a fast transfer of beneficial substances and accurately mimics the release of substances such as glucose or insulin. Due to their benefits, most studies focused on developing microcapsules with low or non-inflammatory responses. This feature is used successfully in the treatment of endocrine diseases [77].

Many biocompatible polymers have been used as encapsulation materials. For this, a biopolymer must meet certain criteria: (i) stable and not interacting with the drug it contains; (ii) not interfering with the function and cellular viability; non-toxic, inexpensive, and biodegradable; (iii) both the biopolymer and its degradation products must be nonantagonistic to the host; (iv) molecular weight, solubility characteristics, glass transition temperature, microstructure, and chemical functionality should allow for proper drug diffusion and release; (v) biosafe and biocompatible; and (vi) when biocompatibility needs to be improved, the biopolymer should be combined with other compounds for a synergistic effect.

Depending on the mechanism that controls the release of the active agent from the delivery system, the controlled-release modalities may be different. Thus, biopolymer erosion, diffusion, and swelling, followed by diffusion or degradation, may occur [78]. The erosion mechanisms involve: (i) hydrolysis of hydrogels, an important feature for the controlled release of macromolecules; (ii) solubilization of water-insoluble biopolymers by reactions with groups pendant from the polymer covalently bonded atoms; and (iii) cleavage of hydrolytically labile bonds within the biopolymer covalently bonded atoms. The diffusion process occurs when an encapsulated drug or other active agent crosses the outer membrane of the capsule through the biopolymer used for the controlled-release device. In the case of diffusion-controlled systems, the drug delivery system must be stable in the biological environment and must maintain its size and shape through the swelling or degradation [79]. For example, when biopolymers are combined with other bioactive agents, the drug must be able to diffuse through their molecular structure or through pores when it reaches the biological environment. At this stage, it is very important that there are no changes to the biopolymer itself. Swelling-controlled release devices are those systems that, although dry in the initial phase, will swell when they reach the body and 
come into contact with fluids or water. The swelling ability of the biopolymers can be triggered by changing the environmental conditions of the delivery system. This is one of the most important and useful features of the biopolymers because, by changing the $\mathrm{pH}$ or temperature, the release of drugs or incorporated active substances can be controlled [80]. Finally, the biodegradation of a biopolymer in the body is a natural process through which the active ingredient is completely eliminated.

Synthetic polymers have long been of interest for use as encapsulating agents of various therapeutic substances. Although they show improved pharmacokinetics compared to small molecule drugs, their accumulation in the body has raised toxicity issues [81]. With the reorientation of the medical industry towards the use of biopolymers, the major issue is the selection of the right compounds based on the need and desired effects. Not all biopolymers are suitable as encapsulating agents for drugs. It is important that they release the active substance to the target area at the right time in a safe manner and without side effects, especially considering that the predominant routes are oral or intravenous administration [82]. The most used biopolymers and which are the focus of this review are those based on polysaccharides, such as sodium alginate, chitosan, agar, starch, and cellulose. They react synergistically with other biopolymers and polymers, have low toxicity and non-immunogenic behavior, and are compatible with tissues and cells. These polysaccharides are stable in vitro and in vivo, and are used in the development of microcapsules, microspheres, or nanocapsules. When tested in vivo, they showed high biocompatibility and biodegradability, facilitating treatment, minimizing side effects, and improving the health condition. Their high solubility is a plus for their use as disintegrants in water-soluble tablets. For example, when used in tablets, the coating of chitosan and starch improved their visual appearance, protected the drug from degradation, and masked the unpleasant taste of the incorporated substance [83]. When used as capsule material, gelatin was replaced with alginate, a vegan version, or with cellulose, for hard capsules. The main biopolymers that are widely used and presented in this review are alginate, chitosan, agar, starch, and cellulose.

\section{Alginate and Its Use for Drug Delivery}

Alginate is probably the most widely used biopolymer in the pharmaceutical and medical industries. This is due to its special encapsulation properties and role in wound healing. It was first isolated in the 1980s and since then it became a multifunctional compound in many applications. Thus, it is obtained at low cost and is a renewable and readily available, biodegradable, non-toxic, biocompatible, and, importantly, mucoadhesive and non-immunogenic compound [84]. It is recognized in the pharmaceutical industry as an excipient and is used to treat reflux esophagitis [85].

Structurally, alginate is a hidrosoluble polysaccharide formed from alternative blocks of 1-4 linked $\alpha$-L-guluronic acid and $\beta$-D-mannuronic acid residues. It contains varying lengths of G-blocks, M-blocks, and/or MG/GM-blocks. High G content alginates have the ability to form stiffer, brittle, and more porous gels, but with increased strength, while high $\mathrm{M}$ content alginates tend to obtain more elastic and weaker gels [86].

Alginate is obtained from brown algae and is found as alginic acid sodium, calcium, and magnesium salts. The algae species used for the extraction of trading alginates are Macrocystis pyrifera, Laminaria hyperborea, Saccharina japonica, and Ascophyllum nodosum. It can be synthesized by various species of bacteria such as Azotobacter vinelandii and various Pseudomonas species, although they are not commercially available [72]. Alginate extraction is achieved by a relatively simple process. First, the raw material from the algae is ground and washed with acid followed by the extraction with hot alkali. The alginic acid is obtained after the extract has been filtered, precipitated with calcium, and acidified. The required salt form of alginate is obtained by treating insoluble alginic acid with metallic carbonates, oxides, or hydroxides [87]. Alginate biocompatibility has been extensively studied, with data showing that oral administration of alginate does not trigger many immune responses, in addition to the finding that it is non-toxic and biodegradable [88]. 
By contrast, intravenous administration of most commercial alginates can lead to adverse body reactions and fibrosis [89].

As an encapsulating agent, alginate was first used in the treatment of diabetes in the encapsulation of pancreatic islet cells [90]. Since then, it has been used for both macro and microencapsulation, and for other endocrine and recombinant cells for the release of therapeutic gene products such as growth hormones or human clotting factor IX (Table 2). It is also used in bioartificial organs such as they kidneys or for the protection of hepatocytes or parathyroids. Alginate gels cannot provide immunoprotection because they are too porous. Therefore, in most applications, alginate gels must be coated with cationic polymers of synthetic origin. For alginate-based coatings, the most used cationic polymers are poly-Llysine and poly-L-ornithine, but lately polyethylene glycol (PEG), glutaraldehyde, chitosan, and agarose have also been applied. Occasionally, other substances are used to reduce permeability, to ensure mechanical stability, and to increase the durability of the capsules; however, PEG remains the most used coating material. Another way to stabilize alginate gels is through the application of covalent crosslinking molecules, although this method of encapsulation interferes with the functional viability of the cells and can lead to cell toxicity [91].

Table 2. Alginate use for drug delivery.

\begin{tabular}{|c|c|c|c|c|}
\hline Biopolymers & Entrapped Substances & Applications & Benefits & References \\
\hline Alginate & Rifampicin & Drug delivery carriers & $\begin{array}{l}\text { Nanoparticles are } \mathrm{pH} \text { sensitive with } \\
\text { the highest release of the active } \\
\text { substance occurring at a pH of } 7.4 \text {. } \\
\text { Toxicity and safety tests were excellent } \\
\text { with no systemic toxicity after oral } \\
\text { administration of nanoparticles. } \\
\text { Controlled drug release }\end{array}$ & [92] \\
\hline Alginate & Ibuprofen & Drug delivery system & $\begin{array}{c}\text { maintained for } 4 \mathrm{~h} \text { (67.53\% of the } \\
\text { drug formulation). }\end{array}$ & [93] \\
\hline $\begin{array}{l}\text { Alginate and } \\
\text { methylcellulose }\end{array}$ & Indomethacin & Drug delivery carrier & $\begin{array}{l}\text { Controlled drug release. There was no } \\
\text { interaction between the loaded drug } \\
\text { and the polymers. }\end{array}$ & [94] \\
\hline Alginate & $\begin{array}{c}\text { Metformin } \\
\text { hydrochloride }\end{array}$ & Drug delivery system & $\begin{array}{l}\text { Good release time; microspheres may } \\
\text { be used in the treatment of diabetes. } \\
\text { The drug: polymer (ratio 1:3) was }\end{array}$ & [95] \\
\hline Alginate & $\begin{array}{l}\text { Diclofenac } \\
\text { sodium }\end{array}$ & $\begin{array}{l}\text { Controlled-release } \\
\text { microparticles }\end{array}$ & $\begin{array}{l}\text { obtained by emulsification and the } \\
\text { drug release followed zero order } \\
\text { kinetics, optimum for controlled drug } \\
\text { release delivery. }\end{array}$ & [96] \\
\hline $\begin{array}{l}\text { Alginate and sodium } \\
\text { carboxymethylcellulose }\end{array}$ & Ceftriaxone sodium & Multiarticulate beads & $\begin{array}{c}\text { The use of the biopolymer matrix } \\
\text { decreased drug release in gastric } \\
\text { conditions but sustained it at intestinal } \\
\text { pH. The beads swelled at pH } 1.2 \text { but } \\
\text { particle diffusion and erosion occurred } \\
\text { at pH } 6.8 \text {. }\end{array}$ & [97] \\
\hline Alginate & Furosemide & $\begin{array}{l}\text { Controlled drug } \\
\text { delivery beads }\end{array}$ & $\begin{array}{l}\text { Drug release was controlled due to the } \\
\text { thicker membrane and reduced beads } \\
\text { swelling. Release of Furosemide } \\
\text { depends on the conditions of the } \\
\text { coating treatment. }\end{array}$ & [98] \\
\hline Alginate & Isoniazid & $\begin{array}{l}\text { Oral drug } \\
\text { delivery }\end{array}$ & $\begin{array}{c}\text { Microspheres were present in the } \\
\text { intestinal lumen } 4 \mathrm{~h} \text { after } \\
\text { administration and were detectable in } \\
\text { the intestine after } 24 \mathrm{~h} \text { of oral } \\
\text { administration. Approximately } 26 \% \text { of } \\
\text { the drug was released in the } \\
\text { gastrointestinal fluid ( } \mathrm{pH} 1.2 \text { ) in } 6 \mathrm{~h} \\
\text { and } 71.25 \% \text { in the simulated intestinal } \\
\text { fluid (pH } 7.4 \text { ) in } 30 \mathrm{~h} \text {. }\end{array}$ & [99] \\
\hline
\end{tabular}


Table 2. Cont

\begin{tabular}{|c|c|c|c|c|}
\hline Biopolymers & Entrapped Substances & Applications & Benefits & References \\
\hline Alginate & Nicotinic acid & Aerogels & $\begin{array}{l}\text { The release of the drug was prolonged } \\
\text { when the core was surrounded by } \\
\text { several alginate-based membranes. } \\
\text { Due to coating, } 50 \% \text { of the drug was } \\
\text { released within } 4 \mathrm{~h} \text {. }\end{array}$ & [100] \\
\hline $\begin{array}{c}\text { Alginate, } \\
\text { carboxymethylcellulose, } \\
\text { and chitosan }\end{array}$ & Amoxicillin & Coated beads & $\begin{array}{l}\text { In gastric } \mathrm{pH} \text { conditions, the drug } \\
\text { release was prolonged from } 61 \mathrm{~min} \text { to } \\
\text { up to } 8 \mathrm{~h} \text {. }\end{array}$ & \\
\hline
\end{tabular}

Thus, based on its characteristics, alginate seems to be the most suitable biopolymer used for drug encapsulation (Table 2). This is due to its specific properties, especially as a matrix for controlled drug delivery devices. In addition, alginate is cheap and readily available, is accepted for consumption in quantum statis doses, is nontoxic, and ensures the protection of the mucous membranes of the upper gastrointestinal tract [101].

\section{Chitosan and Its Use for Drug Delivery}

Chitosan is a polysaccharide found in shellfish, fungi, annelids, mollusks, and insects. It is the second most outspread natural polysaccharide on Earth, after cellulose. Commercially, it is produced from chitin, being a poly $\beta(1 \rightarrow 4)$-2-amino-2-deoxy- $\beta$-D-glucan deacetylated chitin. It has a strong affinity for polyanions, contains reactive $\mathrm{NH}_{3}{ }^{+}$and $\mathrm{OH}^{-}$ groups, and is soluble in acidic aqueous solutions. It is nontoxic, odorless, bio-compatible, and biodegradable. Due to its antibacterial properties, chitosan is used for microencapsulation, in particular for cells that require a cationic environment. Numerous applications in drug delivery include drug targeting systems for oral, nasal, ocular, and transdermal routes [102]. For this purpose, chitosan has been used in the development of gels, films, oral tablets, beads, and microspheres [103].

The capacity of chitosan as an encapsulating agent is greatly influenced by its molecular weight, degree of deacetylation and crystallinity, and extent of ionization/the free amino group. Thus, when the amino group at the 2-position of glucosamine units of chitosan is the main site for the immobilization of thiol groups, it results in thiolated chitosan. The thiolated chitosan derivatives are chitosan-cysteine, chitosan-thiolactic acid, chitosan-thioglycolicacid, chitosan-homocystenine, chitosan-N-acetylcysteine, and chitosan-glutathione. The thiolated chitosan has been used for anticancer drugs because it offers efficient mucoadhesivity, membrane permeation, and an enhancing capability and improved inhibition for P-glycoprotein [104]. Phosphorylated chitosan and its derivatives have different features such as high hidrosolubility and a metal chelating tendency, used in tissue regeneration, drug delivery intermediates, fuel cells, and in the food industry [105].

Structurally, chitosan is composed of free amine groups in media with a $\mathrm{pH}$ over 7.5 and protonated amines are formed in media with a lower $\mathrm{pH}$. These $\mathrm{pH}$-sensitive characteristics make chitosan-based compounds suitable in controlled-release technologies. Under well-established conditions, chitosan microcapsules containing the drug as an active ingredient permits its slow release at the target site [106]. For example, when encapsulated in chitosan, lipophilic drugs were effectively released into the intestinal tract [107]. When used as a vehicle to encapsulate vaccines, it allowed for their controlled release and delivery to targeted sites [108].

There are a number of advantages in using chitosan in the pharmaceutical industry for drug delivery, such as: (i) the controlled release of encapsulated substances; (ii) the elimination of toxic agents in the development process (due to dissolution in aqueous solution); (iii) crosslinking readily available free amino groups; and (iv) improved membrane absorption by mixing cationic chitosan with an anionic material [109]. When used as a coating agent for nanoparticles for the treatment of brain disease, chitosan protects against enzyme degradation, controls release, and improves bioavailability. In addition, it enhances drug permeability across the blood-brain barrier by affecting tight junctions [110]. 
Equally important are its hemostatic, bacteriostatic, anticholesterol, anticarcinogenic, and fungal characteristics.

In addition, chitosan has good bioadhesive properties and slows down the drug release in the nasal cavity, thus increasing bioavailability and the transfer of drugs from the nasal cavity to the brain [111]. When chitosan was used in membrane development, it increased permeability to acidic drugs. It is insoluble at a $\mathrm{pH}$ greater than 6.5 and prevents the burst effect of the release in the first segments of the gastrointestinal tract [112]. It has also been used successfully for antiviral and antibiotic encapsulation, as seen from Table 3 .

Table 3. Chitosan use for drug delivery.

\begin{tabular}{|c|c|c|c|c|}
\hline Biopolymers & $\begin{array}{l}\text { Entrapped } \\
\text { Substances }\end{array}$ & Applications & Benefits & References \\
\hline Chitosan & Acyclovir & Drug delivery system & $\begin{array}{l}\text { The grafting efficiency was } 94 \% \text { and the slow release } \\
\text { of the drug was prolonged to } 12 \mathrm{~h} \text {. }\end{array}$ & [113] \\
\hline Chitosan & $\begin{array}{l}\text { Chlorhexidine } \\
\text { diacetate }\end{array}$ & Buccal tablets & $\begin{array}{l}\text { The tablets dissolved more quickly in vitro than } \\
\text { chlorhexidine powder and both maintained and even } \\
\text { improved the antimicrobial activity of the drug, } \\
\text { particularly against Candida albicans, due to } \\
\text { antimicrobial activity of the polymer itself. }\end{array}$ & [114] \\
\hline $\begin{array}{l}\text { Chitosan aspartate, } \\
\text { glutamate, and } \\
\text { hydrochloride }\end{array}$ & Vancomycin & Peptidic model drug & $\begin{array}{l}\text { The sustained release from the microspheres } \\
\text { minimized its solubilization in the upper } \\
\text { gastrointestinal tract. }\end{array}$ & [115] \\
\hline Chitosan & Tetracycline & $\begin{array}{l}\text { Controlled drug } \\
\text { system }\end{array}$ & $\begin{array}{l}\text { The concentration of drug released was above the } \\
\text { minimum limit required for the inhibition of } \\
\text { Staphylococcus aureus. }\end{array}$ & [116] \\
\hline $\begin{array}{l}\text { Chitosan and } \\
\text { oleic acid }\end{array}$ & Camptothecin & $\begin{array}{l}\text { Controlled drug } \\
\text { system }\end{array}$ & $\begin{array}{l}\text { The encapsulation efficiency was about } 78 \% \text {. When } \\
\text { its effectiveness in the simulated gastrointestinal } \\
\text { fluids was tested, the drug was released slowly into } \\
\text { the gastric environment. In intestinal fluids, the drug } \\
\text { release was controlled. The drug embedded in } \\
\text { chitosan was } 75 \% \text { protected from hydrolysis. }\end{array}$ & [117] \\
\hline Chitosan & Satranidazole & $\begin{array}{l}\text { Subgingival films for } \\
\text { periodontitis }\end{array}$ & $\begin{array}{l}\text { The drug was released for } 96 \mathrm{~h} \text {; the population of } \\
\text { gram-positive bacteria was reduced. }\end{array}$ & [118] \\
\hline Chitosan and alginate & Amygdalin & $\begin{array}{l}\text { Drug delivery } \\
\text { system }\end{array}$ & $\begin{array}{l}\text { The controlled amygdalin release was performed for } \\
10 \mathrm{~h} \text {; the maximum amygdalin released was } 70.46 \% \text { at } \\
\text { pH } 3.1,81.86 \% \text { at pH 5.0, and } 86.03 \% \text { at pH } 7.4 \text {. }\end{array}$ & [119] \\
\hline $\begin{array}{l}\text { Chitosan and } \\
\text { graphene }\end{array}$ & Isosfamide & $\begin{array}{l}\text { Sustained drug } \\
\text { microspheres }\end{array}$ & $\begin{array}{l}\text { The drug diffusion was the most controlled for when } \\
\text { isosfamide was entrapped in microspheres. }\end{array}$ & [120] \\
\hline $\begin{array}{l}\text { Chitosan and } \\
\text { xanthan gum }\end{array}$ & Ciprofloxacin & $\begin{array}{l}\text { Controlled-release } \\
\text { hydrogel }\end{array}$ & $\begin{array}{l}\text { The entrapment efficiency of the prepared hydrogel } \\
\text { increased with the drug increasing concentration and } \\
\text { the maximum was reached at } 93.8 \% \text {. }\end{array}$ & [121] \\
\hline Chitosan & Interferon- $\alpha$ & $\begin{array}{l}\text { Nanoparticles for } \\
\text { oral delivery }\end{array}$ & $\begin{array}{l}\text { In mice, the nanoparticles were found in plasma at } \\
1 \mathrm{~h} \text { after administration, unlike the commercial } \\
\text { interferon which could not be detected. }\end{array}$ & [122] \\
\hline
\end{tabular}

Chitosan has been extensively used as a matrix for extended drug release, especially due to the simple obtaining procedure, low cost, and biocompatibility. The biocompatibility of chitosan also derives from the fact that it is already part of the human food chain due to its presence in numerous fungi [123]. Chitosan increases the solubility of insoluble drugs when used in mixtures with inorganic nanoparticles, forming a stable complex with safe delivery to the specific site. It was effective when encapsulated hemoglobin, astaxanthin, quercetin, vaccines, or vitamins. Besides its applicability in drug delivery, chitosan is also used in wound dressing, tissue engineering, bioimaging, biosensors, and packaging, among other uses [124].

\section{Agar and Its Use for Drug Delivery}

Agar is a long-chain biopolymer obtained from species of algae from the Rhodophyceae class, most commonly found in Gelidium sp. and Gracilaria sp. It represents the supporting structure of algae and is composed of a mixture of agarose and agaropectin, the gelling and the non-gelling fraction, respectively [125]. Agaropectin is usually removed during processing in order to obtain an agar powder with higher gel strength. Agarose is com- 
posed of repetitive units of D-galactose and 3-6, anhydro-L-galactose, linked by alternating $\alpha-(1 \rightarrow 3)$ and $\beta$ - $(1 \rightarrow 4)$ glycosidic bonds.

The ratio of agarose to agaropectin depends largely on seaweed growth, the environmental condition of seaweed growth, extraction methods, and rheological and gelling properties. These changes affect the final mechanical properties of the gels [126]. Agar quality can be significantly improved by modification, which is the most widely used chemical method. It involves hydroxypropylation, acetylation, etherification, and oxidation, the last one being the most commonly used [127]. Due to its gelling capacity, gel reversibility, and high hysteresis, agar is intensely used in various applications, mainly in the food industry, due to its ability to form gel and have an odorless taste. The most important agar evaluation index is gel strength, an important feature for pricing and developing new applications. The easiest way to improve agar characteristics is to remove the sulfate groups with hydrogen peroxide. Thus, after modification, the viscosity, ash content, and sulfate content decreased. Conversely, the gel strength, whiteness, and transparency increased after modification, in contrast to gelling, melting, and dissolving temperatures that decreased after modification [128]. Unlike other biopolymers, agar has been widely used as an encapsulating agent for probiotics since 1988 [129]. The method followed a simple way of encapsulation, which involves the use of drug microparticles and their dispersing at high temperatures in a hydrophilic liquid vehicle. After cooling, due to the transition to ambient temperature, the beads solidify. The same encapsulation method is currently used both for agar and other biopolymers used for this purpose [130]. The method depends on dropping a hot hydrophilic polymeric solution on the top of a cooled organic liquid, such as ethyl acetate which is a non-toxic compound, during which the polymer and the incorporated drug are insoluble. Usually, when only agar is used as an encapsulating agent, the release of the drug occurs in two phases. The first and faster phase leads to the release of $10-20 \%$ of the drug, based on the agar content of the beads. The second is a slower and more prolonged phase and becomes even slower as dissolution proceeds. In the first phase, the drug presents in a molecular state on the surface and is released in the outer layer of the bead so that in the second phase, its release is due to dissolution from the solid core. When used as an encapsulating agent, the larger the mass of agar in the beads, the denser the matrix formed and the lower the transfer of drug molecules through the beads. Similarly, the beads that contain a lower percentage of agar in the composition have a higher water content, which explains the rapid rate of drug release [131]. Therefore, agar can be used for the development of sustained-release dosage systems because it is a natural, inert, non-toxic, renewable, biocompatible, and inexpensive material.

\section{Starch and Its Use for Drug Delivery}

Starch is one of the most abundant renewable biopolymers on Earth and is nonallergenic, GRAS (generally recognized as safe), and cheap [132]. It is found in peas, corn, rice, wheat, potato, and beans [133]. Starch granules vary in size, shape, particle size distribution, and in the amylose-amylopectin ratio depending on the botanical origin and maturity [134]. The high encapsulation efficiency was reached when the amylose:amylopectin ratio was 25:75 [135]. Starch granules are composed of amylose and amylopectin, free fatty acids and lysophopholipids, proteins, phosphate esters, and water [136]. Amylose is the linear fraction and is composed of glucopyranose units linked by $\alpha-(1,4)$-glycosidic linkages, while amylopectin is a highly branched polymer with short $\alpha-(1,4)$-glycosidic chains linked by $\alpha-(1,6)$-glycosidic branching points [137]. Although amylopectin has a high viscosity and is a good thickening agent, it produces very weak gels with poor mechanical properties [138]. Starch is a biopolymer available in the form of powders, hydrogels, films, and sponges [139]. Due to its low cost, physicochemical features, biodegradability, and biocompatibility, native and modified starch has been widely used in the food, chemical, pharmaceutical, and environmental industries [140].

In the pharmaceutical and medical industries, starch has been used as a pharmaceutical excipient, a tablet super disintegrant (immediate release tablet formulations), and a 
controlled/sustained-release polymer or as plasma volume expander, useful for patients suffering from trauma, heavy blood loss, or in cancer treatment [141]. Research has focused on the ability of native starch to be dissolved by pancreatic enzymes after oral ingestion, followed by absorption from the small intestine into the systemic circulation. There is also a resistant part of starch that is not digested in the small intestine and is fermented by colonic bacteria. When used as an encapsulant for drugs, it is combined with other biopolymers precisely to limit or attenuate enzymatic degradation in the stomach, thus facilitating the absorption of an adequate amount of the therapeutic agent [142]. In pharmacotherapy, the main objective of such a system is to provide controlled drug release and prevent fluctuations of active substances in the blood in order to maintain drug plasma concentration within the optimal range, in accordance with therapeutic recommendations.

Starch with high crystallinity levels has been explored as an encapsulation matrix. In order to be used successfully in drug delivery and other industries, starch can be modified so that the physicomechanical properties are adjusted to maximize its use. Starch can be modified by chemical, physical, enzymatic, and genetic processes. Of these, chemical process is used most frequently due to its non-disintegrating nature and potential increase in the functionality of the modified starch. The applications of starch as an encapsulating agent of active substances are presented in Table 4 .

Table 4. Applications of starch for drug delivery.

\begin{tabular}{|c|c|c|c|c|}
\hline Biopolymers & Entrapped Substances & Applications & Benefits & References \\
\hline Corn starch & $\begin{array}{l}\text { Chlorhexidine } \\
\text { gluconate }\end{array}$ & $\begin{array}{l}\text { Long-term drug delivery } \\
\text { system }\end{array}$ & $\begin{array}{c}\text { In vitro drug release was observed for } \\
21 \text { days and it inhibited } \\
\text { Staphylococcus aureus growth. }\end{array}$ & [134] \\
\hline Corn starch & Clonidine & Transdermal patches & $\begin{array}{l}\text { Transdermal patches with a single dose } \\
\text { of } 30 \mu \mathrm{g} \text { hydrogel had an effect } 15 \mathrm{~min} \\
\text { after application in treated mice. }\end{array}$ & [143] \\
\hline Corn starch & Salicylic acid & Hydrogel membrane & $\begin{array}{l}\text { The diffusion of the drug through the } \\
\text { membrane was } 4.11 \times 10^{-6} \mathrm{~cm}^{2} / \mathrm{s} \text {. The } \\
\text { hydrogel was tested as an artificial skin } \\
\text { for transferring nutrients or medicines, or } \\
\text { for healing substances to the target area. }\end{array}$ & [144] \\
\hline $\begin{array}{l}\text { Corn starch/ethylene } \\
\text { vinyl } \\
\text { alcohol blend }\end{array}$ & $\begin{array}{c}\text { Non-steroid } \\
\text { anti-inflammatory agent }\end{array}$ & Drug delivery carriers & $\begin{array}{l}\text { In vitro tests showed an immediate burst } \\
\text { effect, followed by a slower, controlled } \\
\text { release of the drug that lasted up to } \\
10 \text { days. }\end{array}$ & [145] \\
\hline Potato starch & $\begin{array}{l}\text { Ibuprofen, benzocaine, } \\
\text { and sulphapyridine }\end{array}$ & $\begin{array}{l}\text { Starch-based } \\
\text { stable carriers }\end{array}$ & $\begin{array}{l}\text { Encapsulation altered starch digestion; } \\
\text { resistant starch was available in the colon } \\
\text { for fermentation. }\end{array}$ & [146] \\
\hline $\begin{array}{l}\text { Glutinous rice starch, } \\
\text { sodium alginate, and } \\
\text { calcium chloride }\end{array}$ & Metformin hydrochloride & $\begin{array}{l}\text { Hydrogel beads for } \\
\text { controlled drug delivery }\end{array}$ & $\begin{array}{l}\text { The initial drug entrapment efficiency } \\
\text { was very low for the metformin } \\
\text { hydrochloride because of its high } \\
\text { solubility. Encapsulation improved it } \\
\text { when combined with pre-gelatinized } \\
\text { starch gel. }\end{array}$ & [147] \\
\hline Ensete ventricosum starch & Epichlorohydrin & $\begin{array}{l}\text { Drug-release sustaining } \\
\text { pharmaceutical excipient }\end{array}$ & $\begin{array}{l}\text { The in vitro drug release profile showed } \\
\text { a minimum burst release, followed by a } \\
\text { sustained release for } 12 \mathrm{~h} \text {. }\end{array}$ & [148] \\
\hline Starch-clay composites & Tramadol & Tablet formulations & $\begin{array}{l}\text { The controlled drug release of tramadol } \\
\text { from starch-clay biocomposites was } \\
\text { achieved in approximately } 350 \text { min. }\end{array}$ & [149] \\
\hline Starch-chitosan & Hydroxyurea & Cancer therapy & $\begin{array}{l}\text { The drug release was sensitive to } \mathrm{pH} \text { and } \\
\text { increased in the acid environment. The } \\
\text { drug/starch/chitosan had a toxicity } \\
\text { effect and, at certain concentrations, } \\
\text { killed cancer cells. }\end{array}$ & [150] \\
\hline PVA-corn starch hydrogel & Erythromycin & Wound dressing & $\begin{array}{c}\text { The release of erythromycin from the } \\
\text { PVA/corn starch network was higher } \\
\text { than the drug containing PVA hydrogel } \\
\text { (after } 1800 \text { min, released } 76.7 \text { mg of the } \\
\text { total drug). }\end{array}$ & [151] \\
\hline
\end{tabular}


Table 4. Cont.

\begin{tabular}{|c|c|c|c|c|}
\hline Biopolymers & Entrapped Substances & Applications & Benefits & References \\
\hline $\begin{array}{l}\text { Corn starch-sponge } \\
\text { matrix }\end{array}$ & $\begin{array}{l}\text { Uranine, indomethacin, } \\
\text { and nifedipine }\end{array}$ & Sustained-release capsule & $\begin{array}{l}\text { After intraduodenal administration, } 2.5 \% \\
\text { of the capsule exhibited a sustained } \\
\text { release of the drug in the plasma. }\end{array}$ & [152] \\
\hline Starch-poly- $\varepsilon$ caprolactone & Dexamethasone & $\begin{array}{l}\text { Drug delivery and tissue } \\
\text { engineering applications }\end{array}$ & $\begin{array}{l}\text { The drug from the outermost layer of the } \\
\text { microparticles was quickly released. } \\
\text { In vitro tests showed a sustained-release } \\
\text { pattern for } 30 \text { days. }\end{array}$ & [153] \\
\hline $\begin{array}{l}\text { High-amylose } \\
\text { starch-microcrystalline } \\
\text { cellulose }\end{array}$ & Ranitidine hydrochloride & $\begin{array}{l}\text { Gastric-floating drug } \\
\text { delivery systems }\end{array}$ & $\begin{array}{c}\text { In vitro tests indicated that the system } \\
\text { with 3:7 (wt./wt.) starch/cellulose ratio } \\
\text { maintained the buoyancy for more than a } \\
\text { day; the drug release was } 45.87 \% \text { in the } \\
\text { first hour, followed by a sustained } \\
\text { release for up to } 10 \mathrm{~h} \text {. }\end{array}$ & [154] \\
\hline Maize starch & $\begin{array}{c}\text { Probiotics, e.g., } \\
\text { Lactobacillus plantarum }\end{array}$ & $\begin{array}{l}\text { Microencapsulated } \\
\text { probiotic }\end{array}$ & $\begin{array}{l}\text { In low acid environments, L. plantarum } \\
\text { encapsulated in the starch matrix was } \\
\text { more stable. After simulated digestion } \\
\text { and heating treatments, the cells } \\
\text { maintained their high viability, unlike } \\
\text { formulations with native starch }\end{array}$ & {$[155]$} \\
\hline
\end{tabular}

Most starch-based drug delivery systems have been developed with starches extracted from potato, maize, corn, cassava, and wheat [118]. As shown in Table 4, starch is a viable source of biopolymer, used as an encapsulating agent for controlled drug delivery systems. In its unmodified form, starch is not as effective as a drug delivery system due to poor mechanical properties, such as low shear stress resistance or high retrogradation and syneresis, thermal decomposition, reduced processability, and solubility in common organic solvents [156]. However, after modification, starch can be used successfully for this purpose. For example, modifying starch in order to obtain resistant starch has led to its use for improving the gut microbiota population with a role in modulating signaling pathways associated with anti-inflammation, anti-diabetes, and anti-obesity [157]. Resistant starch, due to its high amylose content and low amylopectin, has been recognized as a healthy food for humans and animals. It can be considered prebiotic and may reach the colon due to its resistance to digestion by pancreatic enzymes in the small intestine [158]. Therefore, encapsulation has been suggested as the best approach to improve prebioticprobiotic symbiosis.

\section{Cellulose and Its Use for Drug Delivery}

Cellulose, a natural polymer, is the most renewable and abundant polysaccharide. Cellulose has been used as an immunoprotective macrocapsule because it does not form a hydrogel and it is mostly applied in inert diffusion chambers. As an encapsulating agent, it is beneficial for cytotoxic epithelial cells in the treatment of pancreatic cancer, insulin-producing cell lines (HIT-T15), embryonic kidney cells, and hybridoma cells. It is recognized as a new nanovehicle for oral colorectal cancer treatment with high drug release at a neutral $\mathrm{pH}$ compared to acid $\mathrm{pH}$, being proposed as a safe oral delivery system for controlled colon cancer treatment [159].

Cellulose is the structural part of the cell wall of green plants, algae, or oomycetes. It is part of the polysaccharide group and is composed of a linear chain of $\beta(1 \rightarrow 4)$-linked D-glucose units. Considering it has an amphiphilic character, it can be used as a surfactant and/or stabilizer at the water-oil interface in pickering emulsions [160]. Cellulose is insoluble in water and most organic solvents. The cellulose derivative, carboxy-methylcellulose $(\mathrm{CMC})$, contains carboxymethyl groups bound to the $\mathrm{OH}$-groups of glucopyranose monomers on the cellulose backbone. CMC is mostly applied as a matrix molecule and, in order to ensure mechanical stability and immunoprotection, requires surface coating. CMC has been used as an encapsulating agent for probiotics, but due to the hydrophilicity of the cellulose derivatives, physical degradation occurs when passing through the digestive system. Combined with alginate, it provides a better medium system for probiotics with 
enhanced tolerance at low $\mathrm{pH}$ and a more durable delivery of probiotic cells. Long-term storage stability depends on low water activity and low temperature. The most used dehydration methods to reduce water activity are freeze-drying, spray-drying, vacuumdrying, convective air-drying, and fluidized bed-drying. Among all, freeze-drying is the best method for preserving cells' viability because it reduces the damage to biological structures by eliminating water through sublimation [155].

Cellulose crystals have been used in combination with chitosan to encapsulate vitamin C. Stability of vitamin $\mathrm{C}$ is highly dependent on light, $\mathrm{pH}$, and the dissolved oxygen in the environment, but is maintained due to the encapsulation with cellulose and chitosan crystals, and this may be a way to preserve highly unstable compounds during long-term storage in functional systems [161]. Similarly, nanofibrillated cellulose, combined with soybean oil-in-water emulsion and whey protein isolate, was used to encapsulate vitamin D3. Vitamin D3 encapsulation efficiency has improved with increasing emulsifier concentrations. Increasing the concentration of nanofibrillated cellulose has improved the stability and efficiency of encapsulation against environmental stresses ( $\mathrm{pH}$ changes, salt addition, and thermal processing). The procedure may be the basis for more suitable encapsulation technologies for liposoluble vitamins in emulsion-based food products [162].

In addition to encapsulating vitamins, cellulose and cellulose derivatives have been used as agents to encapsulate drugs and probiotics with active substances. For example, ethyl cellulose nanoparticles have been shown to be effective in encapsulating clarithromycin (3:1 weight ratio of ethyl cellulose:clarithromycin). Once encapsulated, clarithromycin was more effective against Helicobacter pylori gastric infections. Tests performed in vivo on laboratory mice have clearly indicated better elimination of bacteria from the stomach by encapsulated clarithromycin compared to the nonencapsulated drug [163]. Ethyl cellulose and microcrystalline cellulose were also used for the encapsulation of antihypertensive drugs. This is important considering that, in the standard method of manufacturing microspheres involving emulsification and solvent evaporation, the solvents used are usually dichloromethane or chloroform, which are hazardous for the environment. Therefore, less toxic substances such as ethyl acetate are used to prepare the microspheres. Furthermore, the drug release from the microspheres is faster than the tableted ones, suggesting that tableting of the microparticulate systems may be optimal [163].

\subsection{Biopolymers in Probiotic Encapsulation and Delivery}

Due to their special properties, biopolymers have been used to encapsulate probiotics. Probiotics are living organisms with benefits on the hosts' health if ingested in adequate amounts [164]. According to the International Scientific Association for Probiotics and Prebiotics (ISAPP), a sufficient amount of probiotics with a beneficial effect on the hosts health involves ingesting $1 \times 10^{9} \mathrm{CFU}$ per serving [165]. Unlike probiotics, prebiotics are nutrients, usually high-fiber foods, providing the substrate that is selectively utilized by the hosts' microorganisms, conferring a health benefit [165]. Most probiotics in the human body form the commensal intestinal microbiota with a role in increasing resistance to infections and boosting host immune system, glucose and lipid metabolism, degradation of complex carbohydrates, and synthesis of vitamins and bile acid [166]. Although the effects of probiotics on various diseases is still debatable, several studies showed beneficial effects in the treatment and prevention of infectious diseases. For example, strains of Lactobacillus plantarum, Lactobacillus casei, or Lactobacillus paracasei had antifungal, antibacterial, and antioxidant effects. Other strains have been shown to have anti-inflammatory effects, to lessen the risk of osteoporosis, maintain cholesterol levels, and prevent the proliferation of cancer cells [167]. Therefore, due to their beneficial effects and health claims, there has been a worldwide explosion of probiotic-based health products in the form of dietary supplements [168]. As such, the global probiotic market is soon reaching USD 50 billion and, with that, the range of probiotics-containing products and associated health claims continue to expand rapidly. Currently, in Europe, the probiotic market is subject to regulatory 
requirements and compliance with rules and regulations in order to meet certain standards for product registration and use [169].

The use of encapsulation technologies of probiotics has been intensely studied in order to increase probiotics' viability throughout manipulation, storage, commercialization, and incorporation in food and pharmaceutical products so that these cells are viable during their transit and residence in the gastrointestinal tract. Therefore, improving probiotic survival and resistance to adverse conditions through encapsulation is paramount to their effectiveness in health and disease conditions. To prove their effectiveness, encapsulated probiotic strains have been incorporated into a wide range of food products such as yoghurt [170], cheeses [171], frozen dairy desserts [172], beverages [173], and meat products [174], increasing their therapeutic effects [168]. Once encapsulated, probiotics embedded in food matrices maintained their viability even two months under refrigeration [175]. They can also be mixed in a single microcapsule or in dual core capsules with separation microcompartments [176] and a combination of at least two strains can improve their effect [174]. In order to scale up production, several industrial partnerships between food producers and probiotic companies have been formed. For example, Christian Hansen and Dos Pinos developed probiotic ice cream, Balchem Encapsulates and Rosell Institute developed probiotic raisins and bars, and Dannon uses probiotics encapsulated in their products [177]. Encapsulated probiotics have been effective in irritable bowel syndrome [178], colitis, abdominal pain [179], and other gut or metabolic conditions characterized by microbiota dysbiosis [180].

Several encapsulation methods have been developed and used.

(1) Microencapsulation represents a physicochemical or mechanical process used to trap a substance (active agent) into a coating material (defined as wall material). In this way, spherical particles have a thin and strong but semipermeable membrane with a diameter from nanometers to a few millimeters [174]. The purpose of the procedure is to protect compounds or viable cells against environmental agents that can destroy the core [181].

(2) Spray-drying technique is suitable for industrial applications on a large scale, involving atomization of a liquid mixture and the solvent is evaporated at contact with hot air or gas.

(3) Lyophilization involves freezing the cells with the material used for encapsulation (usually at freezing temperatures), followed by vacuum elimination of water at a pressure between 0.05 to $0.1 \mathrm{mBar}$ and temperature between $-50{ }^{\circ} \mathrm{C}$ to $-30{ }^{\circ} \mathrm{C}$. To preserve and stabilize the activity of lyophilized probiotics, cryoprotectants are added, such as lactose, trehalose, sorbitol, sucrose, milk protein, or skim milk.

(4) Extrusion is the most common technique to use biopolymers as encapsulation materials. The method involves obtaining a hydrocolloid solution, followed by the addition of microorganisms, formation of droplets using a syringe needle (pilot scale) or an extruder (industrial scale), and their release into a hardening solution (typically calcium chloride) [182].

(5) Emulsion is when a small volume of a hydrocolloid suspension containing microorganisms (discontinuous phase) is added to a larger volume of vegetable oil (continuous phase). Using an emulsifier, the mixture is homogenized. After emulsion formation, it can be insolubilized to manufacture gel capsules. The big disadvantage of this method is that the particles obtained vary greatly in shape and size, although bead sizes can be reduced by mechanical homogenization [183].

(6) Spray-freeze-drying is a combined procedure that involves steps used in lyophilization (freeze-drying) and spray-drying. The advantage is that it provides capsules with a controlled size and higher specific surface area, unlike those obtained by spray-drying. The disadvantages of the method refers to high costs (approximately 50 times higher than the classic spray-drying version), long processing times, and the high-energy requirement. 
(7) Layer-by-layer is technology based on alternating coating layers of cationic (e.g., chitosan) with anionic (e.g., alginate) biopolymers on cells via electrostatic interaction [184]. It has the advantage of enhanced bacterial viability throughout the gastrointestinal tract, along with the survival of probiotic cells against acidic and bile salt insults, mucoadhesion and growth on intestinal tissues, and in vivo survival [179].

In addition to ensuring cell viability along the gastrointestinal tract, the stability of probiotics during storage is also very important. In this regard, encapsulation has proved to be an effective method. For this, the material used to encapsulate microorganisms is the first and most important factor in maintaining their viability [185]. It improves the survival of probiotics during manufacturing processes, especially heat processing [186] and storage [187]. An important aspect of this process is cytotoxicity. According to ISO 10993-5 [188], a material used for encapsulation is potentially cytotoxic when cell viability decreases below 70\% after exposure [189]. In this regard, polysaccharides such as alginate, starch, chitosan, and cellulose, as well as other biopolymers or chemicals, have low or no toxicity and do not affect cell viability. On the contrary, they maintained cellular stability for a long time, particularly when kept in refrigerated or frozen conditions.

Although the encapsulation method has many advantages, there are still several aspects that must be consider. These are: (i) biosafety concerns preventing clinical translation of the cell microencapsulation; (ii) concerns regarding the manipulation and extraction procedures that must be refined in order to be as minimally invasive as possible; (iii) concerns regarding the optimization of cost effectiveness; and (iv) concerns regarding the consideration of internationally accepted regulations for the use of probiotics. Therefore, applications of biopolymers for the coating of encapsulated strains for the purpose of protection in the intestinal gastrointestinal tract or as carriers for direct encapsulation of microorganisms should involve procedures that facilitate high bacterial viability.

\subsubsection{Alginate's Use for Probiotic Delivery}

Among biomaterials used for encapsulation, alginate is the most widely used due to its strong gelling properties and ability to coat within a short time. Additionally, as a dietary fiber, alginate strengthens the functionality of probiotics used in several diseases such as diabetes or obesity [190]. As seen from Table 5, alginate has proven to be a good microencapsulation agent by extending cell viability in refrigeration and freezing conditions, as well as in adverse gastric and intestinal environments.

Table 5. Utilization of alginate as a probiotic encapsulating material.

\begin{tabular}{|c|c|c|c|c|}
\hline Biopolymers & Encapsulated Strain & Encapsulation Method & Benefits & References \\
\hline Alginate and gelatin & Lactobacillus rhamnosus & Extrusion & $\begin{array}{l}\text { The cells of L. rhamnosus survived in beads with } \\
10^{5} \mathrm{CFU} / \mathrm{g} \text { after four months (initially } \\
10^{9} \mathrm{CFU} / \mathrm{g} \text { ). }\end{array}$ & [191] \\
\hline Alginate & $\begin{array}{c}\text { Lactococcus lactis spp. } \\
\text { cremoris }\end{array}$ & Extrusion & $\begin{array}{l}\text { No release of bacteria in the stomach simulated } \\
\text { condition (first } 120 \mathrm{~min} \text { ) or the survival in the } \\
\text { intestinal fluid until } 240 \mathrm{~min} .\end{array}$ & [192] \\
\hline Alginate & $\begin{array}{c}\text { Bifidobacterium } \\
\text { pseudocatenulatum }\end{array}$ & Extrusion & $\begin{array}{l}\text { None of the uncoated probiotic cells survived } \\
\text { after immersion in the simulated small intestine } \\
\text { fluid. By contrast, } 5.6 \log 10 \mathrm{CFU} / \mathrm{g} \text { of viable } \\
\text { probiotic cells remained in the tested microgels. }\end{array}$ & [193] \\
\hline Alginate & $\begin{array}{l}\text { Staphylococcus succinus } \\
\text { and Enterococcus fecium }\end{array}$ & Extrusion & $\begin{array}{l}\text { The encapsulated cells showed } 98.75-88.75 \% \text { of } \\
\text { viability in simulated gastric fluids. Survival } \\
\text { was constant throughout the storage time and } \\
\text { decreased from } 8.1 \text { log CFU } / \mathrm{mL} \text { to } 7.9 \text { log } \\
\mathrm{CFU} / \mathrm{mL} \text { after } 30 \text { days of storage at } 4^{\circ} \mathrm{C} \text {. }\end{array}$ & [194] \\
\hline Alginate and milk & Lactobacillus bulgaricus & Extrusion & $\begin{array}{l}\text { The viability of the encapsulated probiotic was } \\
\text { the same after } 120 \text { min of incubation in an acid } \\
\text { medium (simulated gastric fluid with pH } 2.5 \text { ). } \\
\text { The viability of encapsulated L. bulgaricus was } \\
\text { kept at } 8 \text { log CFU/g after } 120 \text { min of incubation } \\
\text { at pH 2.0. Stability of the encapsulated } \\
\text { probiotic can be preserved for one month after } \\
\text { storage at } 4{ }^{\circ} \mathrm{C} \text {. }\end{array}$ & [195] \\
\hline
\end{tabular}


Table 5. Cont.

\begin{tabular}{|c|c|c|c|c|}
\hline Biopolymers & Encapsulated Strain & Encapsulation Method & Benefits & References \\
\hline Alginate and starch & Lactobacillus fermentum & Lyophilization & $\begin{array}{l}\text { The survival rate of the probiotic was } \\
\text { significantly higher for microparticles blended } \\
\text { with starch than those with no starch. }\end{array}$ & [196] \\
\hline $\begin{array}{l}\text { Alginate, chitosan, } \\
\text { and locust beam }\end{array}$ & Lactobacillus rhamnosus & Freeze-drying & $\begin{array}{l}\text { In contrast to the alginate-based capsules, the } \\
\text { alginate locust beam capsules improved stress } \\
\text { tolerance }(6 \times \text { for freeze-drying, } 100 \times \text { for } \\
\text { thermotolerance, and } 10 \times \text { for acid }) \text {. }\end{array}$ & [197] \\
\hline Alginate and chitosan & $\begin{array}{c}\text { Saccharomyces cerevisiae } \\
\text { Y235 }\end{array}$ & Emulsification & $\begin{array}{l}\text { The viable microencapsulated cells were kept } \\
\text { at } 7.00 \log \mathrm{CFU} / \mathrm{g} \text { after six months at }-20^{\circ} \mathrm{C} \\
\text { and remained } 6.29 \log \mathrm{CFU} / \mathrm{g} \text { after incubation } \\
\text { in SGF for } 2 \mathrm{~h} \text { and in SIF for } 12 \mathrm{~h} \text {, reaching the } \\
\text { standard value }\left(10^{6}-10^{7} \mathrm{CFU} / \mathrm{g}\right) .\end{array}$ & [198] \\
\hline Alginate and chitosan & $\begin{array}{c}\text { Bifidobacterium } \\
\text { pseudocatenulatum }\end{array}$ & & $\begin{array}{c}\text { The highest stability of } B . \text { pseudocatenulatum } \\
\text { was at the highest concentrations of alginate } \\
(4.41 \mathrm{~g} / 100 \mathrm{~mL}) \text { and chitosan }(0.56 \mathrm{~g} / 100 \mathrm{~mL}) \text {. } \\
\text { Resistance of alginate-chitosan capsule in SGF } \\
\text { was better than in SIF. }\end{array}$ & [199] \\
\hline Alginate and chitosan & Bifidobacterium breve & Layer-by-layer & $\begin{array}{l}\text { Three-layer coated matrix was the best method } \\
\text { to increase viability from }<3 \log \mathrm{CFU} / \mathrm{mL} \text {, seen } \\
\text { in encapsulated cells, up to a maximum of } \\
8.84 \pm 0.17 \log \mathrm{CFU} / \mathrm{mL} \text { upon exposure to } \\
\text { in vitro gastric conditions. Multilayer-coated } \\
\text { alginate released their loads to the intestine } \\
\text { with a gradual delivery over } 240 \mathrm{~min} \text {. }\end{array}$ & [200] \\
\hline $\begin{array}{l}\text { Alginate, starch, } \\
\text { and chitosan }\end{array}$ & Lactobacillus acidophilus & Extrusion & $\begin{array}{l}\text { Biopolymers ensured better stability of } \\
\text { probiotics after exposure to SGF and SIF with } \\
6.35 \text { log CFU/g, while lower counts were } \\
\text { noticed for freeze-dried microcapsules. During } \\
\text { storage, cell viability of the probiotics stored in } \\
\text { the freeze-dried form was up to six logs for } \\
30 \text { days and } 135 \text { days in the moist form when } \\
\text { kept at room temperature. }\end{array}$ & [201] \\
\hline $\begin{array}{l}\text { Alginate, chitosan, } \\
\text { and xanthan gum }\end{array}$ & Lactobacillus plantarum & Extrusion & $\begin{array}{l}\text { Sequential incubation of biopolymers in SGF } \\
\text { and SIF facilitated high survival of } L \text {. plantarum } \\
(95 \%) \text { at } \mathrm{pH}<2 \text {. Encapsulation improved } \\
\text { storage stability of L. plantarum at } 4{ }^{\circ} \mathrm{C} \text {. }\end{array}$ & [202] \\
\hline
\end{tabular}

Abbreviations: CFU/g, colony-forming unit per gram; CFU/mL, colony-forming unit per milliliter; SGF, simulated gastric fluids; and SIF, simulated intestinal fluids.

Alginate is hemocompatible, does not accrue in organs, is water soluble, biodegradable, and can form gels under mild conditions. It develops gel at ambiental temperatures and prevents the destruction of the activity of thermolabile drugs. By cross-linking with other agents, it forms insoluble gel that delays the drug release. However, alginates have low mechanical properties, therefore they must be reinforced by combining with other biopolymers or with various conjugates in order to obtain both ionically and covalently cross-linkable capsules.

\subsubsection{Chitosan Use for Probiotic Delivery}

Like other polymers, chitosan has been used to encapsulate probiotics. The bestperforming formulas were identified in combinations of chitosan with other biopolymers such as alginate, agar, or gelatin. The most used combination is with alginate, in which chitosan is used as a final layer of microcapsules (Table 6). This is because at pH 7, chitosan that is positively charged develops strong bonds with gelatin and agar, which are negatively charged [203]. What sets chitosan apart is its antibacterial properties as it is a cationic polysaccharide. The disadvantage of chitosan, however, is the need for solubilization in an acidic environment. Usually, acetic acid is used to solubilize the powder and obtain the coating-forming solution without turbidity, which occurs when a compound has not been fully solubilized [204]. Chitosan cannot be used individually as an encapsulating agent with a role in maintaining cell viability. This is because it increases cell membrane permeability, leading, in the end, to cell loss [205]. Due to this, chitosan is mixed with other natural substances when used as an encapsulating agent. 
Table 6. Chitosan use for probiotic encapsulation.

\begin{tabular}{|c|c|c|c|c|}
\hline Biopolymers & Encapsulated Strain & Encapsulation Method & Benefits & References \\
\hline $\begin{array}{l}\text { Chitosan, agar, } \\
\text { and gelatin }\end{array}$ & Lactobacillus plantarum & Emulsification & $\begin{array}{l}\text { Particles with a diameter of approximately } \\
6 \mathrm{~mm} \text { did not solubilize in SGF } 20 \text { min after } \\
\text { exposure. Cell viability in the biopolymer-free } \\
\text { formula decreased completely after } 2 \mathrm{~h} \text {, unlike } \\
\text { coated particles whose viability was } 9.2 \mathrm{CFU} / \mathrm{g} \\
\text { after } 2 \mathrm{~h} \text {. }\end{array}$ & [206] \\
\hline Chitosan and alginate & $\begin{array}{l}\text { vaccine with } \\
\text { Lactobacillus plantarum }\end{array}$ & Extrusion & $\begin{array}{c}\text { The oral vaccine containing } L . \text { plantarum, used } \\
\text { against spring viremia of carp virus, was } \\
\text { effective even after } 56 \text { days due to the } \\
\text { encapsulation. }\end{array}$ & [207] \\
\hline $\begin{array}{l}\text { Chitosan and } \\
\text { xanthan gum }\end{array}$ & Pediococcus acidilactici & Extrusion & $\begin{array}{l}\text { The encapsulated cells maintained their cell } \\
\text { viability for } 8 \mathrm{~h} \text { in the gastrointestinal fluid with } \\
\text { maximum release occurring after } 24 \mathrm{~h} \text {. The } \\
\text { encapsulated cells maintained their viability for } \\
\text { three days when tested in deionized water. }\end{array}$ & [208] \\
\hline Chitosan and alginate & Bifidobacterium breve & Extrusion & $\begin{array}{l}\text { In an acidic medium ( } \mathrm{pH} 2) \text {, cell viability was } \\
\text { maintained for } 1 \mathrm{~h} \text {. As } \mathrm{pH} \text { increased ( } 4 \text { and } 5) \text {, } \\
\text { cell viability increased to } 120 \mathrm{~min} \text {. After } 2 \mathrm{~h} \text {, the } \\
\text { swelling ratio decreased, a sign that the } \\
\text { microcapsules began to disintegrate. Chitosan } \\
\text { maintained cellular stability at } \mathrm{pH} 4 \text { and } 5 \text {, and } \\
\text { alginate at } \mathrm{pH} 2 \text {. }\end{array}$ & [209] \\
\hline Chitosan and alginate & $\begin{array}{c}\text { Lactobacillus reuteri } \\
\text { DSM } 17938\end{array}$ & Vibration technology & $\begin{array}{c}\text { Unencapsulated cells were more labile to } \\
\text { gastrointestinal stress conditions (reduction by } \\
2.09 \log \text { cycles after } 3 \mathrm{~h} \text { ). The encapsulated ones } \\
\text { resisted better with a reduction of } \\
0.82 \log \text { cycles. }\end{array}$ & [210] \\
\hline Chitosan and alginate & Saccharomyces boulardii & Extrusion & $\begin{array}{c}\text { Encapsulation of strains with chitosan and } \\
\text { alginate facilitated maintenance of cell viability } \\
\text { up to } 6 \mathrm{~h} \text { after administration in mice. }\end{array}$ & [211] \\
\hline Chitosan and alginate & L. acidophilus and L. casei & Extrusion & $\begin{array}{c}\text { Galactooligosaccharides potentiated the effect } \\
\text { of microencapsulation. Cell viability was } \\
\text { reduced by } 3.1 \text { logs for L. acidophilus and } \\
2.9 \text { logs for L. casei when tested at a very low } \\
\text { pH (1.55) of SIF. }\end{array}$ & [212] \\
\hline Chitosan and alginate & $\begin{array}{l}\text { Bacteria strain } 4.1 . Z \\
\text { (B. amyloliquefaciens, } \\
\text { B. subtilis, and } \\
\text { B. methylotrophicus) }\end{array}$ & Vibration and extrusion & $\begin{array}{l}\text { After lyophilization, the microcapsules } \\
\text { maintained their viability }\left(10^{6}-10^{7} \mathrm{CFU} / \mathrm{g}\right) \text { for } \\
\text { about two months under refrigeration. } \\
\text { Chitosan maintained the integrity of capsules } \\
\text { for } 24 \mathrm{~h} \text {. }\end{array}$ & [213] \\
\hline Chitosan and alginate & $\begin{array}{c}\text { Lactobacillus reuteri } \\
\text { KUB-AC5 }\end{array}$ & Emulsification & $\begin{array}{c}\text { The viability of non-encapsulated cells } \\
\text { decreased in } 40 \text { min from } 8 \text { logs CFU/mL to } \\
<4 \log \text { CFU } / \mathrm{mL} \text {, being completely eliminated } \\
\text { after } 1 \mathrm{~h} \text {. The encapsulated cells were much } \\
\text { more stable with a reduction of } 1 \log \mathrm{CFU} / \mathrm{mL} \\
\text { after } 180 \mathrm{~min} \text { at } \mathrm{pH} 1.8 .\end{array}$ & [214] \\
\hline $\begin{array}{l}\text { Chitosan and } \\
\text { hydrochloride- } \\
\text { alginate }\end{array}$ & Bacillus licheniformis & $\begin{array}{l}\text { Orifice-polymerization } \\
\text { method }\end{array}$ & $\begin{array}{c}\text { The chitosan coating protected the } \\
\text { microcapsules; cell release (6.19 CFU/mL) in } \\
1 \mathrm{~h} \text { in SGF (pH 2) and } 4 \mathrm{~h} \text { in the simulated } \\
\text { intestinal fluid ( } \mathrm{pH} \text { 6). }\end{array}$ & [215] \\
\hline
\end{tabular}

Abbreviations: $\mathrm{CFU} / \mathrm{g}$, colony-forming unit per gram; CFU/mL, colony-forming unit per milliliter; SGF, simulated gastric fluids; and SIF, simulated intestinal fluids.

Although the effectiveness of chitosan encapsulation has been demonstrated, it does not appear to be the best biopolymer for probiotic encapsulation. Besides the fact that it cannot be used individually and produces turbidity, the obtained microparticles are usually larger in size, more porous, wrinkled [213], sticky, and the aggregation is worsened [211]. However, utilization of chitosan should not be limited as chitosan improves potential bioadhesion and facilitates the controlled release of bacteria [213].

\subsubsection{Agar Use for Probiotic Delivery}

Agar is one of the polysaccharides intensively used to obtain tablets or other formulas of drugs released in the gastrointestinal tract, but is less used as an encapsulating agent for probiotics. Although there have been attempts to microencapsulate with agar, when used in 
combination with other biopolymers (Table 6), research on its use is limited. This is due to the higher ability to obtain films and lesser ability to facilitate the development of coatings. These applications are mainly due to the ability of agar to form viscous solutions by solubilizing the powder in water at very high temperatures (over $90^{\circ} \mathrm{C}$ ) in order to obtain a termoreversible gel. Agar cannot produce gel at lower temperatures and high temperatures affect the viability of microorganisms. To date, no working method that could involve the solubilization of agar powder in liquids with lower temperatures has been developed. When used as an encapsulating material for essential oils, the temperature of the filmforming solution is lowered to $40^{\circ} \mathrm{C}$, after which essential oils are incorporated [216,217]. Agar-based films have low mechanical properties such as low tensile strength and poor elasticity. Therefore, in the development of films, it is preferred to mix it with other polysaccharides, proteins, or lipids.

\subsubsection{Starch Use for Probiotic Delivery}

Starch can be used as an encapsulating agent but it has weaker characteristics than alginate, chitosan, or cellulose. In the pharmaceutical field, starch is used mainly for encapsulating drugs or active substances when molded into tablets or oral formulations. This is because starch is strongly hydrophilic and is easily dissolved in liquids at ambient temperatures. However, it has the ability to form very small microspheres constituted in resistant aggregates, allowing for a better protection of the core [218]. For example, when used as an encapsulating agent for L. plantarum, rice starch maintained cell viability both at $4{ }^{\circ} \mathrm{C}$ (refrigeration conditions) and at temperatures above $50^{\circ} \mathrm{C}$. However, as an encapsulating agent, starch proved to be more effective when mixed with other compounds. For example, the combination of starch and alginate resulted in microcapsules with increased probiotics resistance to simulated gastric conditions (Table 7).

Table 7. Starch as an encapsulation material for probiotics.

\begin{tabular}{|c|c|c|c|c|}
\hline Biopolymers & Encapsulated Strain & Encapsulation Method & Benefits & References \\
\hline Rice starch & $\begin{array}{c}\text { Lactobacillus casei, } \\
\text { Lactobacillus brevis, and } \\
\text { Lactobacillus plantarum }\end{array}$ & Extrusion & $\begin{array}{l}\text { The viability of encapsulated cells } \\
\text { (8.27/8.46/7.65 log CFU/g) was kept constant } \\
\text { for two months at refrigeration. In contrast, } \\
\text { non-encapsulated cells lost their viability by } \\
\text { approximately } 3 \log \text { CFU /g during storage. }\end{array}$ & [219] \\
\hline Starch and pectin & Lactobacillus plantarum & Extrusion & $\begin{array}{l}\text { Cell viability was reduced from } 10 \log \text { CFU/g } \\
\text { to } 1 \log \text { CFU/g for free cells maintained for } 2 \mathrm{~h} \\
\text { in gastric conditions (pH 1.5-3). Cells } \\
\text { encapsulated in pectin had higher viability } \\
\text { (4.6 log CFU/g) but the best protection was } \\
\text { observed with the addition of starch to which } \\
\text { the viability increased to } 6.94 \log \text { CFU/g. }\end{array}$ & [220] \\
\hline $\begin{array}{l}\text { Starch from corn } \\
\text { and rice }\end{array}$ & Lactobacillus plantarum & Freeze-drying & $\begin{array}{l}\text { Encapsulated cells showed thermal stability } \\
\text { and maintained their integrity for } 35 \mathrm{~min} \text { at } \\
55^{\circ} \mathrm{C} \text {. Unencapsulated cells subjected to the } \\
\text { same treatment lost their viability by } 63 \% \text { after } \\
\text { only } 10 \text { min of exposure to } 55^{\circ} \mathrm{C} \text {. }\end{array}$ & [221] \\
\hline $\begin{array}{l}\text { Starch, alginate, } \\
\text { chitosan, and inulin }\end{array}$ & $\begin{array}{l}\text { Lactobacillus casei and } \\
\text { Bifidobacterium bifidum }\end{array}$ & Emulsification & $\begin{array}{c}\text { Encapsulated L. casei and B. bifidum lost their } \\
\text { viability when subjected to simulated gastric } \\
\text { conditions for } 120 \mathrm{~min} \text {. Cell viability decreased } \\
\text { from } 25.10 \times 10^{10} \mathrm{CFU} / \mathrm{mL} \text { to } \\
6.30 \times 10^{6} \mathrm{CFU} / \mathrm{mL} \text { for } L \text {. casei. Encapsulated } \\
\text { B. bifidum lost } 4.65 \mathrm{log} / \mathrm{mL} \text { of the bacterial } \\
\text { culture, while the unencapsulated form had } \\
\text { undetectable cell viability after } 90 \mathrm{~min} \text {. }\end{array}$ & [222] \\
\hline Starch and alginate & Lactobacillus fermentum & Emulsification & $\begin{array}{l}\text { Encapsulated in the matrix, cells maintained } \\
\text { viability when stored at } 4{ }^{\circ} \mathrm{C} \text { for } 45 \text { days. In } \\
\text { environmental conditions, however, cells } \\
\text { showed a decrease of } 1.7 \text { log after } 24 \text { h, with } \\
\text { complete loss after } 2 \text { weeks. }\end{array}$ & [196] \\
\hline
\end{tabular}


Table 7. Cont.

\begin{tabular}{|c|c|c|c|c|}
\hline Biopolymers & Encapsulated Strain & Encapsulation Method & Benefits & References \\
\hline Starch & Lactobacillus paracasei & Electrospinning & $\begin{array}{l}\text { Tested at different storage temperatures }(4,25 \text {, } \\
\left.\text { and } 37^{\circ} \mathrm{C}\right), \mathrm{L} \text {. paracasei cells maintained their } \\
\text { initial viability of } 13.6 \times 10 \mathrm{CFU} / \mathrm{mL} \text { when } \\
\text { stored for three weeks at } 4{ }^{\circ} \mathrm{C} \text { and } 25^{\circ} \mathrm{C} \text { but not } \\
\text { at } 37^{\circ} \mathrm{C} \text {. Unencapsulated cells lost about } 90 \% \\
\text { of their viability regardless of the } \\
\text { storage temperature. }\end{array}$ & [223] \\
\hline $\begin{array}{l}\text { Maize starch, } \\
\text { maltodextrin, and } \\
\text { gum arabic }\end{array}$ & Lactobacillus acidophilus & Spray-drying & $\begin{array}{l}\text { After 30days of storage at room temperature, } \\
\text { only strains encapsulated with maltodextrin, } \\
\text { namely gum arabic, maintained their cell } \\
\text { viability of } 10^{6} \mathrm{CFU} / \mathrm{g} \text {. After } 60 \text { days, no } \\
\text { encapsulating material prevented the loss of } \\
\text { cell viability. Of the tested coatings, starch least } \\
\text { protected the bacterial strains. }\end{array}$ & [224] \\
\hline Taro and rice starch & Lactobacillus paracasei & Spray-drying & $\begin{array}{l}\text { When stored, the taro-starch encapsulated } \\
\text { strains were more stable; cells maintained their } \\
\text { viability for a month, both at temperatures of } \\
\qquad 4^{\circ} \mathrm{C} \text { and } 25^{\circ} \mathrm{C} \text {. }\end{array}$ & [218] \\
\hline $\begin{array}{l}\text { Cassava starch } \\
\text { and alginate }\end{array}$ & Lactobacillus brevis & Emulsification & $\begin{array}{c}\text { Encapsulation efficiency was higher than } 89 \% \text {. } \\
\text { In gastrointestinal conditions, cell viability was } \\
\text { better for microcapsules than free cells }(96.07 \% \\
\text { compared to } 76.51 \%) \text {. After } 5 \text { h of maintenance } \\
\text { in the same conditions, viability of } L . \text { brevis } \\
\text { encapsulated cells was } 8.69 \text { log CFU } / \mathrm{mL} \text {, } \\
\text { unlike the non-encapsulated ones with } \\
6.87 \log \text { CFU } / \mathrm{mL} \text {. }\end{array}$ & [225] \\
\hline Starch and alginate & Lactobacillus casei & Extrusion & $\begin{array}{l}\text { The addition of } 2 \% \text { starch to the alginate-based } \\
\text { film-forming solution increased cell viability } \\
\text { from } 4 \times 10^{8} \text { to } 3.1 \times 10^{11} \text {. Increasing starch } \\
\text { did not change the results. Tested under } \\
\text { simulated gastrointestinal conditions, cell } \\
\text { viability was maintained for up to } 6 \mathrm{~h} \text {. }\end{array}$ & [226] \\
\hline
\end{tabular}

\subsubsection{Cellulose Use for Probiotic Delivery}

Carboxymethyl cellulose (CMC) is one of the most widely used forms of cellulose due to the fact that it is the most affordable in terms of spread and cost. Although it is a compound that prevents lipid oxidation and reduces oxygen permeability due to the small number of hydroxyl groups in the structure, CMC is a highly water-soluble compound. This limits its use as an encapsulation material for probiotics as it is degraded in the digestive system. Therefore, when used in combination with other biopolymers such as polysaccharides (carrageenan, alginate, chitosan, and starch), proteins (gelatin), or other natural compounds (inulin), it increased the viability of encapsulated anaerobic probiotics by $36 \%$ [227]. The microencapsulation characteristics of CMC have been improved due to the addition of other substances such as gelatin or carrageenan. In general, the encapsulated probiotics maintained their viability for $120 \mathrm{~min}$ in simulated gastric conditions, regardless of the type of probiotic encapsulated. When lyophilization was used as the encapsulation method, cellulose and alginate maintained the viability of $L$. plantarum for approximately 160 days in refrigeration conditions (Table 8).

Table 8. Cellulose as a probiotic encapsulating material.

\begin{tabular}{|c|c|c|c|c|}
\hline Biopolymers & Encapsulated Strain & Encapsulation Method & Benefits & References \\
\hline CMC and gelatin & Lactobacillus rhamnosus & Emulsification & $\begin{array}{l}\text { After } 120 \text { min of exposure to SGF and SIF, cell } \\
\text { viability was maintained at approximately } \\
77.5 \%(4 \log \text { CFU } / \mathrm{mL}) \text { in capsules and } 60 \% \\
\text { (5 } \log \text { CFU } / \mathrm{mL}) \text { in free cells. }\end{array}$ & {$[228]$} \\
\hline
\end{tabular}


Table 8. Cont.

\begin{tabular}{|c|c|c|c|c|}
\hline Biopolymers & Encapsulated Strain & Encapsulation Method & Benefits & References \\
\hline $\mathrm{CMC}$ and $\mathrm{k}$-carrageenan & Lactobacillus plantarum & Extrusion & $\begin{array}{c}\text { Cellular stability was greatly improved for } \\
\text { encapsulated samples: in an acidic medium } \\
\text { (pH 2), it decreased from } 10 \text { log CFU/g to } 0 \\
\text { after } 90 \text { min (non-encapsulated cells) and to } \\
\text { about } 8 \text { log CFU /g after } 120 \mathrm{~min} \\
\text { (encapsulated cells). During storage for } \\
30 \text { days at } 4{ }^{\circ} \mathrm{C} \text {, cell stability changed from } \\
10 \text { log CFU /g to } 2 \text { log CFU/g (free cells) and } \\
\text { from } 10 \text { log CFU/g to } 7 \text { log CFU/g } \\
\text { (encapsulated cells). }\end{array}$ & [229] \\
\hline Cellulose and pectin & lactic acid bacteria & $\begin{array}{l}\text { High-pressure } \\
\text { microfluidization }\end{array}$ & $\begin{array}{l}\text { Viability of non-encapsulated cells decreased } \\
\text { from } 9.56 \text { to } 5.29 \log \mathrm{CFU} / \mathrm{mL} \text { in an acid } \\
\text { medium, while encapsulation protected cells } \\
\text { (decrease of } 1.88 \log \mathrm{CFU} / \mathrm{mL} \text { after } 2 \mathrm{~h} \text { in the } \\
\text { same conditions). }\end{array}$ & [230] \\
\hline $\mathrm{CMC}$ and inulin & Lactobacillus plantarum & Casting & $\begin{array}{l}\text { Cell viability decreased during storage } \\
\text { whether or not probiotics were encapsulated. }\end{array}$ & [227] \\
\hline $\mathrm{CMC}$ and rice bran & Lactobacillus reuteri & Emulsification & $\begin{array}{l}\text { After heat exposure }\left(85^{\circ} \mathrm{C}, 25 \mathrm{~s}\right) \text {, cell viability } \\
\text { decreased by more than } 57 \% \text {, although } \\
\text { L. reuteri is a thermotolerant bacterium. } \\
\text { However, the survival rate of encapsulated } \\
\text { cells was approximately } 6 \log \mathrm{CFU} / \mathrm{g} \text {. }\end{array}$ & [231] \\
\hline CMC and chitosan & Lactobacillus rhamnosus & Extrusion & $\begin{array}{l}\text { Microencapsulated strains were stable at } \mathrm{pH} \\
\text { 2-4; at the highest } \mathrm{pH} \text { value tested (12.5), all } \\
\text { microcapsules disintegrated. }\end{array}$ & [232] \\
\hline $\begin{array}{l}\text { Cellulose, alginate, } \\
\text { starch, and lecithin }\end{array}$ & Lactobacillus rhamnosus & Extrusion & $\begin{array}{c}\text { Under gastric conditions, viability of } \\
\text { encapsulated cells was } 37 \% \text { higher than that } \\
\text { of free ones. Encapsulation had a positive } \\
\text { effect on storage, in which viability decreased } \\
\text { by } 1.23 \text { log ( } 25 \text { degrees) and } 1.08 \text { log } \\
\text { (4 degrees), unlike free cells in which stability } \\
\text { decreased by } 3.17 \text { and } 1.93 \text {. }\end{array}$ & [233] \\
\hline Cellulose and alginate & Lactobacillus plantarum & $\begin{array}{l}\text { Extrusion and } \\
\text { lyophilization }\end{array}$ & $\begin{array}{l}\text { Lyophilized encapsulated cells showed the } \\
\text { best stability in the simulated gastrointestinal } \\
\text { conditions: gradual release of } \\
2.6 \times 10^{6} \mathrm{CFU} / \mathrm{mL} \text { for } 210 \text { min. When } \\
\text { refrigerated, encapsulated cells maintained } \\
\text { viability for up to } 160 \text { days. }\end{array}$ & [155] \\
\hline Cellulose and alginate & Lactobacillus plantarum & Extrusion-dripping & $\begin{array}{c}\text { After } 120 \text { min in SGF, viability of } \\
\text { non-encapsulated cells decreased by } 66.6 \% \text {, } \\
\text { while encapsulated strains had a } 58.4 \% \text { better } \\
\text { viability than that of free cells. The addition } \\
\text { of cellulose protected the capsules from the } \\
\text { action of pH. }\end{array}$ & [234] \\
\hline
\end{tabular}

Abbreviations: CMC, carboxymethyl cellulose; SGF, simulated gastric fluids; SIF, simulated intestinal fluids; CFU/g, colony-forming unit per gram; and $\mathrm{CFU} / \mathrm{mL}$, colony-forming unit per milliliter.

\section{Challenges and Limitations}

The rapid adoption of the use of biopolymers is still hindered by several factors. First, research thus far has been conducted primarily in vitro; therefore, more in vivo and clinical trials are needed to demonstrate the health benefits of biopolymers and the biocompatibility in various biomedical applications, in particular when used as encapsulation materials for drug delivery. When used for the treatment of various diseases, more studies are needed to assess the appropriate compound: either alone or in combination to achieve the desired payload in a highly regulated and site-specific manner at therapeutically relevant concentrations [227].

A second challenge is to obtain materials with properties similar or better to synthetic products by improving end-use mechanical properties, kinetics and release, thermal resistance, and barrier properties. For example, some products exhibit low mechanical properties, rapid degradation, and high hydrophilic capacity especially in humid or adverse environments, rendering their application unviable. 
Although numerous studies have examined the use of encapsulated probiotics, there is a need for in depth interdisciplinary research that includes microbiologists, medical doctors, and biomaterial, food, agro and chemical engineers. This will lead to better and more efficient prototypes of probiotic encapsulating formulations, to the identification of the most specific/effective probiotic strains, and to the most suitable polymeric carriers applied for product manufacturing. In addition, this will lead to the optimization of the entire process based on the natural characteristics and sensitivity of the selected strain, and will identify ways on how to develop the best formula based on in vitro, in vivo, and pre-clinical techniques considering the release, manufacturing, packaging, transportation, and storage of capsules. Third, the challenges related to costs, economic aspects, and the gap between policy and implementation of the new technologies on a global level need to be addressed in this rapidly emerging field.

\section{Conclusions}

Although research in this area has revolutionized the biomedical and pharmaceutical industries, significant work still lies ahead if we are to effect changes not only at the individual level but also to bring sustained and affordable environmental changes. Biopolymers have proven effective as encapsulation materials for controlled drug release systems. Significant progress has been made on the biocompatibility, biodegradability, and mechanical and thermal properties of the materials involved. However, challenges still remain in developing target-specific carriers that are biocompatible with various delivery routes for providing sustainable release at the target site. Strategies have been proposed to improve stability of polymers, product kinetics, and release time as well as clinical efficiency. For biomedical applications, it is important to develop uniform guidelines for polymer applications in order to improve versatility and safety and avoid contamination. From the evidence presented thus far, it is obvious that among biopolymers, polysaccharides-based applications are the most used in the field due to their protective, physicochemical, and low immunogenicity characteristics. Although they present some limitations, the ability to react synergistically with other biopolymers or other natural or synthetic substances make their applications widely used. More studies evaluating the technical parameter optimization, efficiency of encapsulation with different formulations, and product-loading capacity concerning viability and metabolic activity should be undertaken. For example, studies examining the functional interactions between the polymer networks and the coating materials, in order to improve capsule stability, product metabolic activity, release time, and viability, should be high on the list. Notwithstanding current limitations from the host perspective, the use of polymers, particularly polysaccharides-based, will continue to expand with an eye towards improving polysaccharide-drug interactions, the optimization of pharmacokinetics and pharmacodynamics, and the compatibility of the polysaccharide with the target tissue. Nevertheless, while more research is needed, polymer-based applications are of great benefit for delivering small molecules that are highly effective, biopotent, and safe.

Author Contributions: All authors have contributed equally to this work. All authors have read and agreed to the published version of the manuscript.

Funding: The work was supported by the project titled "The analysis of interrelationship between gut microbiota and the host with applications in the prevention and control of type 2 diabetes", co-financed by the European Regional Development Fund through Competitiveness Operational Program under the contract number 120/16.09.2016.

Institutional Review Board Statement: Not applicable.

Informed Consent Statement: Not applicable.

Data Availability Statement: The data presented in this study are available upon request from the corresponding author.

Conflicts of Interest: The authors declare no conflict of interest. 


\section{References}

1. Rebelo, R.; Fernandes, M.; Fangueiro, R. Biopolymers in medical implants: A brief review. Procedia Eng. 2017, 200, 236-243. [CrossRef]

2. Bala, I.A.; Abdullahi, M.R.; Bashir, S.S. A review on formulation of enzymatic solution for biopolymer hydrolysis. J. Chem. 2017, 6, 9-13.

3. Yadav, P.; Yadav, H.; Shah, V.G.; Shah, G.; Dhaka, G. Biomedical biopolymers, their origin and evolution in biomedical sciences: A systematic review. J. Clin. Diagnostic Res. 2015, 9, 21-25. [CrossRef]

4. Aggarwal, J.; Sharma, S.; Kamyab, H.; Kumar, A. The Realm of Biopolymers and Their Usage: An Overview. Available online: http:/ / www.jett.dormaj.com (accessed on 24 June 2021).

5. Udayakumar, G.P.; Muthusamy, S.; Selvaganesh, B.; Sivarajasekar, N.; Rambabu, K.; Banat, F.; Sivamani, S.; Sivakumar, N.; Hosseini-Bandegharaei, A.; Show, P.L. Biopolymers and composites: Properties, characterization and their applications in food, medical and pharmaceutical industries. J. Environ. Chem. Eng. 2021, 9, 105322. [CrossRef]

6. Pattanashetti, N.A.; Heggannavar, G.B.; Kariduraganavar, M.Y. Smart biopolymers and their biomedical applications. Procedia Manuf. 2017, 12, 263-279. [CrossRef]

7. Rendón-Villalobos, R.; Ortíz-Sánchez, A.; Tovar-Sánchez, E.; Flores-Huicochea, E. The role of biopolymers in obtaining environmentally friendly materials. In Composites from Renewable and Sustainable Materials; InTech: Houston, TX, USA, 2016.

8. Nath, K.; Bhattacharyya, S.K.; Das, N.C. Biodegradable polymeric materials for EMI shielding. In Materials for Potential EMI Shielding Applications; Elsevier: Amsterdam, The Netherlands, 2020; pp. 165-178.

9. Kumar, S.; Thakur, K. Bioplastics-Classification, production and their potential food applications. J. Hill Agric. 2017, 8, 118. [CrossRef]

10. Prajapati, S.K.; Jain, A.; Jain, A.; Jain, S. Biodegradable polymers and constructs: A novel approach in drug delivery. Eur. Polym. J. 2019, 120, 109191. [CrossRef]

11. Arora, S. Biopolymers as Packaging Material in Food and Allied Industry Value Addition of Makhana and Its by-Products View Project. 2018. Available online: https:/ / www.researchgate.net/publication/342765641 (accessed on 1 February 2021).

12. Díez-Pascual, A.M. Synthesis and applications of biopolymer composites. Int. J. Mol. Sci. 2019, 20, 2321. [CrossRef] [PubMed]

13. Qasim, U.; Osman, A.I.; Al-Muhtaseb, A.H.; Farrell, C.; Al-Abri, M.; Ali, M.; Vo, D.V.N.; Jamil, F.; Rooney, D.W. Renewable cellulosic nanocomposites for food packaging to avoid fossil fuel plastic pollution: A review. Environ. Chem. Lett. 2021, 19, 613-641. [CrossRef]

14. Hamouda, T. Sustainable packaging from coir fibers. In Biopolymers and Biocomposites from Agro-Waste for Packaging Applications; Elsevier: Amsterdam, The Netherlands, 2021; pp. 113-126.

15. Shivam, P. Recent developments on biodegradable polymers and their future trends. Int. Res. J. Sci. Eng. 2016, 4, 17-26.

16. Chen, H.; Wang, J.; Cheng, Y.; Wang, C.; Liu, H.; Bian, H.; Pan, Y.; Sun, J.; Han, W. Application of protein-based films and coatings for food packaging: A review. Polymers 2019, 11, 2039. [CrossRef]

17. Swain, S.K.; Pattanayak, A.J.; Sahoo, A.P. Functional Biopolymer Composites; Springer: Berlin, Germany, 2018 ; pp. 159-182.

18. Varma, K.; Gopi, S. Biopolymers and their role in medicinal and pharmaceutical applications. In Biopolymers and Their Industrial Applications; Elsevier: Amsterdam, The Netherlands, 2021; pp. 175-191.

19. Carvalho, A.J.F. Starch: Major sources, properties and applications as thermoplastic materials. In Monomers, Polymers and Composites from Renewable Resources; Elsevier: Amsterdam, The Netherlands, 2008; pp. 321-342. ISBN 9780080453163.

20. Temesgen, S.; Rennert, M.; Tesfaye, T.; Nase, M. Review on spinning of biopolymer fibers from starch. Polymers 2021, 13, 1121. [CrossRef] [PubMed]

21. Gustafsson, J.; Landberg, M.; Bátori, V.; Åkesson, D.; Taherzadeh, M.J.; Zamani, A. Development of bio-based films and 3D objects from apple pomace. Polymers 2019, 11, 289. [CrossRef]

22. Liu, W.; Misra, M.; Askeland, P.; Drzal, L.T.; Mohanty, A.K. “Green” composites from soy based plastic and pineapple leaf fiber: Fabrication and properties evaluation. Polymer 2005, 46, 2710-2721. [CrossRef]

23. Maraveas, C. Production of sustainable and biodegradable polymers from agricultural waste. Polymers 2020, 12, 1127. [CrossRef] [PubMed]

24. Heredia-Guerrero, J.A.; Heredia, A.; Domínguez, E.; Cingolani, R.; Bayer, I.S.; Athanassiou, A.; Benítez, J.J. Cutin from agro-waste as a raw material for the production of bioplastics. J. Exp. Bot. 2017, 68, 5401-5410. [CrossRef] [PubMed]

25. Khrunyk, Y.; Lach, S.; Petrenko, I.; Ehrlich, H. Progress in modern marine biomaterials research. Mar. Drugs 2020, 18, 589. [CrossRef]

26. Kaur, S.; Dhillon, G.S. The versatile biopolymer chitosan: Potential sources, evaluation of extraction methods and applications. Crit. Rev. Microbiol. 2014, 40, 155-175. [CrossRef]

27. Torres, F.G.; Troncoso, O.P.; Pisani, A.; Gatto, F.; Bardi, G. Natural polysaccharide nanomaterials: An overview of their immunological properties. Int. J. Mol. Sci. 2019, 20, 5092. [CrossRef]

28. Velu, R.; Calais, T.; Jayakumar, A.; Raspall, F. A comprehensive review on bio-nanomaterials for medical implants and feasibility studies on fabrication of such implants by additive manufacturing technique. Materials 2020, 13, 92. [CrossRef]

29. Chaitanya, S.; Singh, I. Processing of PLA/sisal fiber biocomposites using direct- and extrusion-injection molding. Mater. Manuf. Processes 2017, 32, 468-474. [CrossRef] 
30. Khanna, S.; Srivastava, A.K. A simple structured mathematical model for biopolymer (PHB) production. Biotechnol. Prog. 2005, 21, 830-838. [CrossRef] [PubMed]

31. Ncube, L.K.; Ude, A.U.; Ogunmuyiwa, E.N.; Zulkifli, R.; Beas, I.N. Environmental impact of food packaging materials: A review of contemporary development from conventional plastics to polylactic acid based materials. Materials 2020, 13, 4994. [CrossRef]

32. Wankhade, V. Animal-derived biopolymers in food and biomedical technology. In Biopolymer-Based Formulations: Biomedical and Food Applications; Elsevier: Amsterdam, The Netherlands, 2020; pp. 139-152. ISBN 9780128168981.

33. Parker, G. Measuring the environmental performance of food packaging: Life cycle assessment. In Environmentally Compatible Food Packaging; Elsevier: Amsterdam, The Netherlands, 2008; pp. 211-237. ISBN 9781845691943.

34. Shankar, S.; Rhim, J.-W. Bionanocomposite films for food packaging applications. In Reference Module in Food Science; Elsevier: Amsterdam, The Netherlands, 2018.

35. Hassan, M.E.; Bai, J.; Dou, D.Q. Biopolymers; Definition, classification and applications. Egypt. J. Chem. 2019, 62, 1725-1737. [CrossRef]

36. Soldo, A.; Miletić, M.; Auad, M.L. Biopolymers as a sustainable solution for the enhancement of soil mechanical properties. Sci. Rep. 2020, 10, 1-13. [CrossRef] [PubMed]

37. Song, J.; Winkeljann, B.; Lieleg, O. Biopolymer-based coatings: Promising strategies to improve the biocompatibility and functionality of materials used in biomedical engineering. Adv. Mater. Interfaces 2020, 7, 2000850. [CrossRef]

38. Gabor, D.; Tita, O. Biopolymers used in food packaging: A review. Acta Univ. Cibiniensis Ser. E Food Technol. 2012, 16, 3-19.

39. Sadasivuni, K.K.; Saha, P.; Adhikari, J.; Deshmukh, K.; Ahamed, M.B.; Cabibihan, J.J. Recent advances in mechanical properties of biopolymer composites: A review. Polym. Compos. 2020, 41, 32-59. [CrossRef]

40. Jummaat, F.; Bashir Yahya, E.; Khalil HPS, A.; Adnan, A.S.; Mohammed Alqadhi, A.; Abdullah, C.K.; Sofea, A.A.; Olaiya, N.G.; Abdat, M.; Hps, K. The role of biopolymer-based materials in obstetrics and gynecology applications: A review. Polymers 2021, 13, 633. [CrossRef]

41. Reddy, M.S.B.; Ponnamma, D.; Choudhary, R.; Sadasivuni, K.K. A comparative review of natural and synthetic biopolymer composite scaffolds. Polymers 2021, 13, 1105. [CrossRef]

42. Olivia, M.; Jingga, H.; Toni, N.; Wibisono, G. Biopolymers to improve physical properties and leaching characteristics of mortar and concrete: A review. In IOP Conference Series: Materials Science and Engineering; Institute of Physics Publishing: Bristol, UK, 2018; Volume 345, p. 012028.

43. Gurgel Adeodato Vieira, M.; Altenhofen da Silva, M.; Oliveira dos Santos, L.; Masumi Beppu, M. Natural-based plasticizers and biopolymer films: A review. Eur. Polym. J. 2011, 47, 254-263. [CrossRef]

44. Polman, E.M.N.; Gruter, G.J.M.; Parsons, J.R.; Tietema, A. Comparison of the aerobic biodegradation of biopolymers and the corresponding bioplastics: A review. Sci. Total Environ. 2021, 753, 131953. [CrossRef]

45. Mohan, S.; Oluwafemi, O.S.; Kalarikkal, N.; Thomas, S.; Songca, S.P. Biopolymers-Application in nanoscience and nanotechnology. In Recent Advances in Biopolymers; InTech: Houston, TX, USA, 2016.

46. Imre, B.; Pukánszky, B. Compatibilization in bio-based and biodegradable polymer blends. Eur. Polym. J. 2013, 49, 1215-1233. [CrossRef]

47. Jayanth, D.; Kumar, P.S.; Nayak, G.C.; Kumar, J.S.; Pal, S.K.; Rajasekar, R. A review on biodegradable polymeric materials striving towards the attainment of green environment. J. Polym. Environ. 2018, 26, 838-865. [CrossRef]

48. Cziple, F.A.; Velez Marques, A.J. Biopolymers Versus Synthetic Polymers. Available online: https: / / creativepegworks.wordpress. com/2015/12/01/biopolymers-vs-synthetic-polymers / (accessed on 26 June 2021).

49. Simionescu, B.C.; Ivanov, D. Natural and synthetic polymers for designing composite materials. In Handbook of Bioceramics and Biocomposites; Springer: Berlin, Germany, 2016; pp. 233-286. ISBN 9783319124605.

50. Gowthaman, N.S.K.; Lim, H.N.; Sreeraj, T.R.; Amalraj, A.; Gopi, S. Advantages of biopolymers over synthetic polymers. In Biopolymers and Their Industrial Applications; Elsevier: Amsterdam, The Netherlands, 2021; pp. 351-372.

51. Luh, T.-Y.; Yang, H.-C.; Lin, N.-T.; Lin, S.-Y.; Lee, S.-L.; Chen, C.-H. OMCOS for functional polymers-double-stranded DNA-like polymers. Pure Appl. Chem. 2008, 80, 819-829. [CrossRef]

52. Colmenares, J.C.; Kuna, E. Photoactive hybrid catalysts based on natural and synthetic polymers: A comparative overview. Molecules 2017, 22, 790. [CrossRef] [PubMed]

53. Ryder, K.; Ali, M.A.; Carne, A.; Billakanti, J. The potential use of dairy by-products for the production of nonfood biomaterials. Crit. Rev. Environ. Sci. Technol. 2017, 47, 621-642. [CrossRef]

54. Maraveas, C. Environmental sustainability of greenhouse covering materials. Sustainability 2019, 11, 6129. [CrossRef]

55. Mtibe, A.; Motloung, M.P.; Bandyopadhyay, J.; Ray, S.S. Synthetic biopolymers and their composites: Advantages and limitationsAn overview. Macromol. Rapid Commun. 2021, 42, 2100130. [CrossRef] [PubMed]

56. Ortelli, S.; Costa, A.L.; Torri, C.; Samorì, C.; Galletti, P.; Vineis, C.; Varesano, A.; Bonura, L.; Bianchi, G. Innovative and sustainable production of biopolymers. In Factories of the Future: The Italian Flagship Initiative; Springer: Berlin, Germany, 2019; pp. 131-148. [CrossRef]

57. Adeyeye, O.A.; Sadiku, E.R.; Reddy, A.B.; Ndamase, A.S.; Makgatho, G.; Sellamuthu, P.S.; Perumal, A.B.; Nambiar, R.B.; Fasiku, V.O.; Inrahim, I.D.; et al. The use of biopolymers in food packaging. In Green Polymers and Their Nanocomposites; Springer: Singapore, 2019; pp. 137-158. [CrossRef] 
58. Wróblewska-Krepsztul, J.; Rydzkowski, T.; Michalska-Pożoga, I.; Thakur, V.K. Biopolymers for biomedical and pharmaceutical applications: Recent advances and overview of alginate electrospinning. Nanomaterials 2019, 9, 404. [CrossRef]

59. Ferraris, S.; Spriano, S.; Scalia, A.C.; Cochis, A.; Rimondini, L.; Cruz-Maya, I.; Guarino, V.; Varesano, A.; Vineis, C. Topographical and biomechanical guidance of electrospun fibers for biomedical applications. Polymers 2020, 12, 2896. [CrossRef]

60. Dhandayuthapani, B.; Yoshida, Y.; Maekawa, T.; Kumar, D.S. Polymeric scaffolds in tissue engineering application: A review. Int. J. Polym. Sci. 2011, 2011, 290602. [CrossRef]

61. Ogueri, K.S.; Jafari, T.; Escobar, I.J.L.; Laurencin, C.T. Polymeric biomaterials for scaffold-based bone regenerative engineering. Regen. Eng. Transl. Med. 2019, 5, 128-154. [CrossRef]

62. Bhatia, S. Natural polymers vs. synthetic polymer. In Natural Polymer Drug Delivery Systems; Springer: Berlin, Germany, 2016; pp. 95-118.

63. Innovative Packaging of Medicines-IJAHR. Available online: https://www.ipinnovative.com/journals/IJAHR/article-full-text/10648 (accessed on 27 June 2021).

64. Zadbuke, N.; Shahi, S.; Gulecha, B.; Padalkar, A.; Thube, M. Recent trends and future of pharmaceutical packaging technology. J. Pharm. Bioallied Sci. 2013, 5, 98-110. [CrossRef]

65. Gheorghita Puscaselu, R.; Amariei, S.; Norocel, L.; Gutt, G. New edible packaging material with function in shelf life extension: Applications for the meat and cheese industries. Foods 2020, 9, 562. [CrossRef]

66. Janes, M.E.; Dai, Y. Edible films for meat, poultry and seafood. In Advances in Meat, Poultry and Seafood Packaging; Elsevier: Amsterdam, The Netherlands, 2012; pp. 504-521. ISBN 9781845697518.

67. Avila-Sosa, R.; Palou, E.; López-Malo, A. Essential oils added to edible films. In Essential Oils in Food Preservation, Flavor and Safety; Elsevier: Amsterdam, The Netherlands, 2016; pp. 149-154. ISBN 9780124166448.

68. Zhao, Y.; Mcdaniel, M. Sensory quality of foods associated with edible film and coating systems and shelf-life extension. In Innovations in Food Packaging; Elsevier: Amsterdam, The Netherlands, 2005; pp. 434-453. ISBN 9780123116321.

69. Min, S.; Krochta, J.M. Antimicrobial films and coatings for fresh fruit and Vegetables. In Improving the Safety of Fresh Fruit and Vegetables; Elsevier: Amsterdam, The Netherlands, 2005; pp. 454-492. ISBN 9781855739567.

70. Mcclements, D.J. Biopolymers in food emulsions. In Modern Biopolymer Science; Elsevier: Amsterdam, The Netherlands, 2009; pp. 129-166. ISBN 9780123741950.

71. Ahmed, Z.; Ahmad, A. Biopolymer produced by the lactic acid bacteria: Production and practical application. In Microbial Production of Food Ingredients and Additives; Elsevier: Amsterdam, The Netherlands, 2017; pp. 217-257.

72. Martau, G.A.; Mihai, M.; Vodnar, D.C. The use of chitosan, alginate, and pectin in the biomedical and food sector-biocompatibility, bioadhesiveness, and biodegradability. Polymers 2019, 11, 1837. [CrossRef]

73. De Vos, P.; Lazarjani, H.A.; Poncelet, D.; Faas, M.M. Polymers in cell encapsulation from an enveloped cell perspective. Adv. Drug Deliv. Rev. 2014, 67-68, 15-34. [CrossRef]

74. Madene, A.; Jacquot, M.; Scher, J.; Desobry, S. Flavour encapsulation and controlled release-A review. Int. J. Food Sci. Technol. 2006, 41, 1-21. [CrossRef]

75. Therapeutic Applications of Cell Microencapsulation-Google Cărți. Available online: https://books.google.ro/books?id=7u9d2

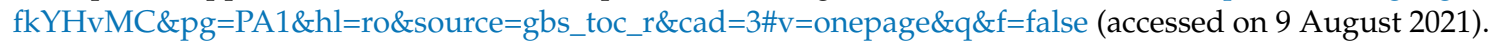

76. Biopolymer Nanoparticles: A Review of Prospects for Application as Carrier for Therapeutics and Diagnostics—Pharmaceutical Research and Allied Sciences. Available online: https://ijpras.com/article/biopolymer-nanoparticles-a-review-of-prospects-forapplication-as-carrier-for-therapeutics-and-diagnostics (accessed on 9 August 2021).

77. Lee, M.K.; Bae, Y.H. Cell transplantation for endocrine disorders. Adv. Drug Deliv. Rev. 2000, 42, 103-120. [CrossRef]

78. Sharma, K.; Singh, V.; Arora, A. Natural biodegradable polymers as matrices intransdermal drug delivery. Int. J. Drug Dev. Res. 2011, 3, 85-103.

79. DJ, M. Designing biopolymer microgels to encapsulate, protect and deliver bioactive components: Physicochemical aspects. Adv. Colloid Interface Sci. 2017, 240, 31-59. [CrossRef]

80. Altomare, L.; Bonetti, L.; Campiglio, C.E.; de Nardo, L.; Draghi, L.; Tana, F.; Farè, S. Biopolymer-based strategies in the design of smart medical devices and artificial organs. Int. J. Artif. Organ 2018, 41, 337-359. [CrossRef]

81. Schmaljohann, D. Thermo- and pH-responsive polymers in drug delivery. Adv. Drug Deliv. Rev. 2006, 58, 1655-1670. [CrossRef]

82. George, A.; Shah, P.A.; Shrivastav, P.S. Natural biodegradable polymers based nano-formulations for drug delivery: A review. Int. J. Pharm. 2019, 561, 244-264. [CrossRef] [PubMed]

83. Polymers in Pharmaceutical Drug Delivery System: A Review. Available online: https://www.researchgate.net/publication/28 5986312_Polymers_in_pharmaceutical_drug_delivery_system_A_review (accessed on 26 July 2021).

84. Paques, J.P.; Van Der Linden, E.; Van Rijn, C.J.M.; Sagis, L.M.C. Preparation methods of alginate nanoparticles. Adv. Colloid Interface Sci. 2014, 209, 163-171. [CrossRef]

85. Severino, P.; da Silva, C.F.; Andrade, L.N.; de Lima Oliveira, D.; Campos, J.; Souto, E.B. Alginate nanoparticles for drug delivery and targeting. Curr. Pharm. Des. 2019, 25, 1312-1334. [CrossRef]

86. De, S.; Robinson, D. Polymer relationships during preparation of chitosan-alginate and poly-l-lysine-alginate nanospheres. $J$. Control. Release 2003, 89, 101-112. [CrossRef]

87. Smith, A.M.; Miri, T. Alginates in Foods. In Practical Food Rheology: An Interpretive Approach; John Wiley\&Sons: Hoboken, NJ, USA, 2010; pp. 113-132. ISBN 9781405199780. 
88. Espevik, T.; Otterlei, M.; Skjåk-Braek, G.; Ryan, L.; Wright, S.D.; Sundan, A. The involvement of CD14 in stimulation of cytokine production by uronic acid polymers. Eur. J. Immunol. 1993, 23, 255-261. [CrossRef]

89. De Vos, P.; De Haan, B.; Pater, J.; Van Schilfgaarde, R. Association between capsule diameter, adequacy of encapsulation, and survival of microencapsulated rat islet allografts. Transplantation 1996, 62, 893-899. [CrossRef] [PubMed]

90. Lim, F.; Sun, A.M. Microencapsulated islets as bioartificial endocrine pancreas. Science 1980, 210, 908-910. [CrossRef]

91. Gattás-Asfura, K.M.; Stabler, C.L. Chemoselective cross-linking and functionalization of alginate via Staudinger ligation. Biomacromolecules 2009, 10, 3122-3129. [CrossRef] [PubMed]

92. Thomas, D.; KurienThomas, K.; Latha, M.S. Preparation and evaluation of alginate nanoparticles prepared by green method for drug delivery applications. Int. J. Biol. Macromol. 2020, 154, 888-895. [CrossRef] [PubMed]

93. Design and Characterization of Ibuprofen Loaded Alginate Microspheres Prepared by Ionic Gelation Method. Available online: https:/ / www.researchgate.net/publication/327743699_Design_and_Characterization_of_Ibuprofen_Loaded_Alginate_ Microspheres_Prepared_by_Ionic_Gelation_Method (accessed on 24 July 2021).

94. Bose, P.S.; Reddy, P.S.; Nagaraju, R. Preparation and evaluation of indomethacin loaded alginate microspheres. Ceska Slov. Farm. 2016, 65, 104-110.

95. Hariyadi, D.M.; Hendradi, E.; Erawati, T.; Jannah, E.N.; Febrina, W. Influence of drug-polymer ratio on physical characteristics and release of metformin hydrochloride from metformin alginate microspheres. Trop. J. Pharm. Res. 2018, 17, 1229-1233. [CrossRef]

96. Ahmed, M.M.; El-Rasoul, S.A.; Auda, S.H.; Ibrahim, M.A. Emulsification/internal gelation as a method for preparation of diclofenac sodium-sodium alginate microparticles. Saudi Pharm. J. 2013, 21, 61-69. [CrossRef] [PubMed]

97. Patel, N.; Lalwani, D.; Gollmer, S.; Injeti, E.; Sari, Y.; Nesamony, J. Development and evaluation of a calcium alginate based oral ceftriaxone sodium formulation. Prog. Biomater. 2016, 5, 117-133. [CrossRef]

98. Setty, C.M.; Sahoo, S.S.; Sa, D.B. Alginate-coated alginate-polyethyleneimine beads for prolonged release of furosemide in simulated intestinal fluid. Drug Dev. Ind. Pharm. 2008, 31, 435-446. [CrossRef] [PubMed]

99. Rastogi, R.; Sultana, Y.; Aqil, M.; Ali, A.; Kumar, S. Alginate microspheres of isoniazid for oral sustained drug delivery. Int. J. Pharm. 2007, 334, 71-77. [CrossRef]

100. Veronovski, A.; Knez, Ž.; Novak, Z. Preparation of multi-membrane alginate aerogels used for drug delivery. J. Supercrit. Fluids 2013, 79, 209-215. [CrossRef]

101. Lee, S.; Kim, Y.C.; Park, J.H. Zein-alginate based oral drug delivery systems: Protection and release of therapeutic proteins. Int. J. Pharm. 2016, 515, 300-306. [CrossRef] [PubMed]

102. Varshosaz, J. The promise of chitosan microspheres in drug delivery systems. Expert Opin. Drug Deliv. 2007, 4, 263-273. [CrossRef]

103. Bakshi, P.S.; Selvakumar, D.; Kadirvelu, K.; Kumar, N.S. Chitosan as an environment friendly biomaterial—A review on recent modifications and applications. Int. J. Biol. Macromol. 2020, 150, 1072-1083. [CrossRef]

104. Negm, N.A.; Hefni, H.H.H.; Abd-Elaal, A.A.A.; Badr, E.A.; Abou Kana, M.T.H. Advancement on modification of chitosan biopolymer and its potential applications. Int. J. Biol. Macromol. 2020, 152, 681-702. [CrossRef]

105. Jayakumar, R.; Reis, R.L.; Mano, J.F. Chemistry and applications of phosphorylated chitin and chitosan. E Polym. 2006, 6, 1-16. [CrossRef]

106. Raza, Z.A.; Khalil, S.; Ayub, A.; Banat, I.M. Recent developments in chitosan encapsulation of various active ingredients for multifunctional applications. Carbohydr. Res. 2020, 492, 108004. [CrossRef] [PubMed]

107. Hussain, S.A.; Abdelkader, H.; Abdullah, N.; Kmaruddin, S. Review on micro-encapsulation with Chitosan for pharmaceuticals applications. MOJ Curr. Res. Rev. 2018, 1,77-84. [CrossRef]

108. Koppolu, B.P.; Smith, S.G.; Ravindranathan, S.; Jayanthi, S.; Suresh Kumar, T.K.; Zaharoff, D.A. Controlling chitosan-based encapsulation for protein and vaccine delivery. Biomaterials 2014, 35, 4382-4389. [CrossRef]

109. Prabaharan, M. Review paper: Chitosan derivatives as promising materials for controlled drug delivery. J. Biomater. Appl. 2008, 23, 5-36. [CrossRef] [PubMed]

110. Yu, S.; Xu, X.; Feng, J.; Liu, M.; Hu, K. Chitosan and chitosan coating nanoparticles for the treatment of brain disease. Int. J. Pharm. 2019, 560, 282-293. [CrossRef] [PubMed]

111. Wang, X.; Chi, N.; Tang, X. Preparation of estradiol chitosan nanoparticles for improving nasal absorption and brain targeting. Eur. J. Pharm. Biopharm. 2008, 70, 735-740. [CrossRef]

112. Panos, I.; Acosta, N.; Heras, A. New drug delivery systems based on chitosan. Curr. Drug Discov. Technol. $2008,5,333-341$. [CrossRef]

113. Rokhade, A.P.; Patil, S.A.; Aminabhavi, T.M. Synthesis and characterization of semi-interpenetrating polymer network microspheres of acrylamide grafted dextran and chitosan for controlled release of acyclovir. Carbohydr. Polym. 2007, 67, 605-613. [CrossRef]

114. Giunchedi, P.; Juliano, C.; Gavini, E.; Cossu, M.; Sorrenti, M. Formulation and in vivo evaluation of chlorhexidine buccal tablets prepared using drug-loaded chitosan microspheres. Eur. J. Pharm. Biopharm. 2002, 53, 233-239. [CrossRef]

115. Cerchiara, T.; Luppi, B.; Bigucci, F.; Petrachi, M.; Orienti, I.; Zecchi, V. Controlled release of vancomycin from freeze-dried chitosan salts coated with different fatty acids by spray-drying. J. Microencapsul. 2003, 20, 473-478. [CrossRef]

116. Govender, S.; Pillay, V.; Chetty, D.J.; Essack, S.Y.; Dangor, C.M.; Govender, T. Optimisation and characterisation of bioadhesive controlled release tetracycline microspheres. Int. J. Pharm. 2005, 306, 24-40. [CrossRef] 
117. Almeida, A.; Araújo, M.; Novoa-Carballal, R.; Andrade, F.; Gonçalves, H.; Reis, R.L.; Lúcio, M.; Schwartz, S.; Sarmento, B. Novel amphiphilic chitosan micelles as carriers for hydrophobic anticancer drugs. Mater. Sci. Eng. C 2020, 112, 110920. [CrossRef]

118. Nair, S.; Anoop, K. Design and in vitro evaluation of controlled release Satranidazole subgingival films for periodontitis therapy. Recent Res. Sci. Technol. 2014, 2, 6-11.

119. Sohail, R.; Abbas, S.R. Evaluation of amygdalin-loaded alginate-chitosan nanoparticles as biocompatible drug delivery carriers for anticancerous efficacy. Int. J. Biol. Macromol. 2020, 153, 36-45. [CrossRef] [PubMed]

120. Shariatinia, Z.; Mazloom-Jalali, A. Chitosan nanocomposite drug delivery systems designed for the ifosfamide anticancer drug using molecular dynamics simulations. J. Mol. Liq. 2019, 273, 346-367. [CrossRef]

121. Hanna, D.H.; Saad, G.R. Encapsulation of ciprofloxacin within modified xanthan gum-chitosan based hydrogel for drug delivery. Bioorg. Chem. 2019, 84, 115-124. [CrossRef] [PubMed]

122. Cánepa, C.; Imperiale, J.C.; Berini, C.A.; Lewicki, M.; Sosnik, A.; Biglione, M.M. Development of a drug delivery system based on chitosan nanoparticles for oral administration of interferon- $\alpha$. Biomacromolecules 2017, 18, 3302-3309. [CrossRef]

123. Sathiyaseelan, A.; Saravanakumar, K.; Anand Mariadoss, A.V.; Wang, M.H. Biocompatible fungal chitosan encapsulated phytogenic silver nanoparticles enhanced antidiabetic, antioxidant and antibacterial activity. Int. J. Biol. Macromol. 2020, 153, 63-71. [CrossRef] [PubMed]

124. Ali, A.; Ahmed, S. A review on chitosan and its nanocomposites in drug delivery. Int. J. Biol. Macromol. 2018, 109, 273-286. [CrossRef]

125. Mostafavi, F.S.; Zaeim, D. Agar-based edible films for food packaging applications-A review. Int. J. Biol. Macromol. 2020, 159, 1165-1176. [CrossRef]

126. Bertasa, M.; Dodero, A.; Alloisio, M.; Vicini, S.; Riedo, C.; Sansonetti, A.; Scalarone, D.; Castellano, M. Agar gel strength: A correlation study between chemical composition and rheological properties. Eur. Polym. J. 2020, 123, 109442. [CrossRef]

127. Zhang, C.; An, D.; Xiao, Q.; Weng, H.; Zhang, Y.; Yang, Q.; Xiao, A. Preparation, characterization, and modification mechanism of agar treated with hydrogen peroxide at different temperatures. Food Hydrocoll. 2020, 101, 105527. [CrossRef]

128. Xiao, Q.; An, D.; Zhang, C.; Weng, H.; Zhang, Y.; Chen, F.; Xiao, A. Agar quality promotion prepared by desulfation with hydrogen peroxide. Int. J. Biol. Macromol. 2020, 145, 492-499. [CrossRef] [PubMed]

129. El-Helw, A.E.R.; El-Said, Y. Preparation and characterization of agar beads containing phenobarbitone sodium. J. Microencapsul. 1988, 5, 159-163. [CrossRef]

130. Evandro, M.; Denis, R.; Zenia, A.; Emre, K.; Denis, P. Oil encapsulation in core-shell alginate capsules by inverse gelation. I: Dripping methodology. J. Microencapsul. 2017, 34, 82-90. [CrossRef]

131. Rivadeneira, J.; Audisio, M.; Gorustovich, A. Films based on soy protein-agar blends for wound dressing: Effect of different biopolymer proportions on the drug release rate and the physical and antibacterial properties of the films. J. Biomater. Appl. 2018, 32, 1231-1238. [CrossRef]

132. Zhu, F. Encapsulation and delivery of food ingredients using starch based systems. Food Chem. 2017, 229, 542-552. [CrossRef] [PubMed]

133. Queiroz, V.M.; Kling, I.C.S.; Eltom, A.E.; Archanjo, B.S.; Prado, M.; Simão, R.A. Corn starch films as a long-term drug delivery system for chlorhexidine gluconate. Mater. Sci. Eng. C 2020, 112, 110852. [CrossRef]

134. Qi, X.; Tester, R.F. Starch granules as active guest molecules or microorganism delivery systems. Food Chem. 2019, 271, 182-186. [CrossRef] [PubMed]

135. Hoyos-Leyva, J.D.; Bello-Pérez, L.A.; Alvarez-Ramirez, J.; Garcia, H.S. Microencapsulation using starch as wall material: A review. Food Rev. Int. 2018, 34, 148-161. [CrossRef]

136. Santana, Á.L.; Angela, M.; Meireles, A. New starches are the trend for industry applications: A review. Food Public Health 2014, 2014, 229-241. [CrossRef]

137. Chen, J.; Wang, Y.; Liu, J.; Xu, X. Preparation, characterization, physicochemical property and potential application of porous starch: A review. Int. J. Biol. Macromol. 2020, 148, 1169-1181. [CrossRef]

138. Šárka, E.; Dvořáček, V. New processing and applications of waxy starch (a review). J. Food Eng. 2017, 206, 77-87. [CrossRef]

139. Hemamalini, T.; Giri Dev, V.R. Comprehensive review on electrospinning of starch polymer for biomedical applications. Int. J. Biol. Macromol. 2018, 106, 712-718. [CrossRef]

140. Wang, B.; Sui, J.; Yu, B.; Yuan, C.; Guo, L.; Abd El-Aty, A.M.; Cui, B. Physicochemical properties and antibacterial activity of corn starch-based films incorporated with Zanthoxylum bungeanum essential oil. Carbohydr. Polym. 2021, 254, 117314. [CrossRef]

141. Singh, A.; Nath, L.; Singh, A. Pharmaceutical, food and non-food applications of modified starches: A critical review. Electron. J. Environ. Agric. Food Chem. 2010, 9, 1214-1221.

142. Rodrigues, A.; Emeje, M. Recent applications of starch derivatives in nanodrug delivery. Carbohydr. Polym. 2012, 87, 987-994. [CrossRef]

143. Saboktakin, M. In-vitro and in-vivo characterizations of novel modified starch transdermal drug delivery system. MOJ Proteom. Bioinform. 2017, 5, 132-135. [CrossRef]

144. Pal, K. Starch based hydrogel with potential biomedical application as artificial skin. Afr. J. Biomed. Res. 2006, 9, 23-29. [CrossRef]

145. Malafaya, P.B.; Elvira, C.; Gallardo, A.; San Román, J.; Reis, R.L. Porous starch-based drug delivery systems processed by a microwave route. J. Biomater. Sci. Polym. Ed. 2001, 12, 1227-1241. [CrossRef] 
146. Janaswamy, S. Encapsulation altered starch digestion: Toward developing starch-based delivery systems. Carbohydr. Polym. 2014, 101, 600-605. [CrossRef] [PubMed]

147. Sachan, N.; Bhattacharya, A. Modeling and characterization of drug release from glutinous rice starch based hydrogel beads for controlled drug delivery. Int. J. Health Res. 2010, 2, 55398. [CrossRef]

148. Tesfay, D.; Abrha, S.; Yilma, Z.; Woldu, G.; Molla, F. Preparation, optimization, and evaluation of epichlorohydrin cross-linked enset (ensete ventricosum (welw.) cheeseman) starch as drug release sustaining excipient in microsphere formulation. BioMed Res. Int. 2020, 2020, 2147971. [CrossRef]

149. Alabi, C.O.; Singh, I.; Odeku, O.A. Evaluation of starch-clay composites as a pharmaceutical excipient in tramadol tablet formulations. Polim. Med. 2020, 50, 33-40. [CrossRef]

150. Starch-Chitosan Modified Blend as Long-Term Controlled Drug Release For Cancer Therapy. Available online: http://staff. uokufa.edu.iq/publication_details.php?khalidahk.abbas\&recordID=6799 (accessed on 26 June 2021).

151. Mehrizi, A.A. Synthesis and Characterization of Erythromycin Loaded PVA-Corn Starch Hydrogel Wound Dressing. Available online: https:/ / www.academia.edu/15627564/Synthesis_and_characterization_of_Erythromycin_loaded_PVA_corn_starch_ hydrogel_wound_dressing (accessed on 26 June 2021).

152. Shibata, N.; Nishumura, A.; Naruhashi, K.; Nakao, Y.; Miura, R. Preparation and pharmaceutical evaluation of new sustainedrelease capsule including starch-sponge matrix (SSM). Biomed. Pharmacother. 2010, 64, 352-358. [CrossRef]

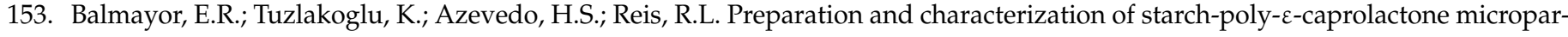
ticles incorporating bioactive agents for drug delivery and tissue engineering applications. Acta Biomater. 2009, 5, 1035-1045. [CrossRef]

154. Xu, J.; Tan, X.; Chen, L.; Li, X.; Xie, F. Starch/microcrystalline cellulose hybrid gels as gastric-floating drug delivery systems. Carbohydr. Polym. 2019, 215, 151-159. [CrossRef] [PubMed]

155. Li, W.; Liu, L.; Tian, H.; Luo, X.; Liu, S. Encapsulation of Lactobacillus plantarum in cellulose based microgel with controlled release behavior and increased long-term storage stability. Carbohydr. Polym. 2019, 223, 115065. [CrossRef]

156. Ab'lah, N.; Wong, T.W. Starch as oral colon-specific nano- and microparticulate drug carriers. In Polymer Science and Innovative Applications; Elsevier: Amsterdam, The Netherlands, 2020; pp. 287-330.

157. Yang, X.; Darko, O.K.; Huang, Y.; He, C.; Yang, H.; He, S.; Li, J.; Li, J.; Hocker, B.; Yin, Y. Resistant starch regulates gut microbiota: Structure, biochemistry and cell signalling. Cell Physiol. Biochem. 2017, 42, 306-318. [CrossRef] [PubMed]

158. Fuentes-Zaragoza, E.; Sánchez-Zapata, E.; Sendra, E.; Sayas, E.; Navarro, C.; Fernández-Lõpez, J.; Pérez-Alvarez, J.A. Resistant starch as prebiotic: A review. Starch Staerke 2011, 63, 406-415. [CrossRef]

159. Pooresmaeil, M.; Behzadi Nia, S.; Namazi, H. Green encapsulation of LDH(Zn/Al)-5-Fu with carboxymethyl cellulose biopolymer; new nanovehicle for oral colorectal cancer treatment. Int. J. Biol. Macromol. 2019, 139, 994-1001. [CrossRef]

160. Li, Y.; Yu, S.; Chen, P.; Rojas, R.; Hajian, A.; Berglund, L. Cellulose nanofibers enable paraffin encapsulation and the formation of stable thermal regulation nanocomposites. Nano Energy 2017, 34, 541-548. [CrossRef]

161. Baek, J.; Ramasamy, M.; Willis, N.C.; Kim, D.S.; Anderson, W.A.; Tam, K.C. Encapsulation and controlled release of vitamin C in modified cellulose nanocrystal/chitosan nanocapsules. Curr. Res. Food Sci. 2021, 4, 215-223. [CrossRef]

162. Mitbumrung, W.; Suphantharika, M.; Mcclements, D.J.; Winuprasith, T. Encapsulation of vitamin D3 in pickering emulsion stabilized by nanofibrillated mangosteen cellulose: Effect of environmental stresses. J. Food Sci. 2019, 84, 3213-3221. [CrossRef]

163. Pan-In, P.; Banlunara, W.; Chaichanawongsaroj, N.; Wanichwecharungruang, S. Ethyl cellulose nanoparticles: Clarithomycin encapsulation and eradication of H. pylori. Carbohydr. Polym. 2014, 109, 22-27. [CrossRef]

164. Serna-Cock, L.; Vallejo-Castillo, V. Probiotic encapsulation. Afr. J. Microbiol. Res. 2013, 7, 4743-4753. [CrossRef]

165. Salminen, S.; Collado, M.C.; Endo, A.; Hill, C.; Lebeer, S.; Quigley, E.M.M.; Sanders, M.E.; Shamir, R.; Swann, J.R.; Szajewska, $\mathrm{H}$; e t al. The international scientific association of probiotics and prebiotics (ISAPP) consensus statement on the definition and scope of postbiotics. Nat. Rev. Gastroenterol. Hepatol. 2021, 2021, 1-19. [CrossRef]

166. Silva, D.R.; Sardi, J.C.O.; Pitangui, N.S.; Roque, S.M.; da Silva, A.C.B.; Rosalen, P.L. Probiotics as an alternative antimicrobial therapy: Current reality and future directions. J. Funct. Foods 2020, 73, 104080. [CrossRef]

167. Misra, S.; Pandey, P.; Mishra, H.N. Novel approaches for co-encapsulation of probiotic bacteria with bioactive compounds, their health benefits and functional food product development: A review. Trends Food Sci. Technol. 2021, 109, 340-351. [CrossRef]

168. Kailasapathy, K. Microencapsulation of Probiotic Bacteria 39 Microencapsulation of Probiotic Bacteria: Technology and Potential Applications. Available online: https:/ / www.caister.com/bacteria-plant (accessed on 27 July 2021).

169. Burgain, J.; Gaiani, C.; Linder, M.; Scher, J. Encapsulation of probiotic living cells: From laboratory scale to industrial applications. J. Food Eng. 2011, 104, 467-483. [CrossRef]

170. Kailasapathy, K. Encapsulation technologies for functional foods and nutraceutical product development. CAB Rev. 2009, 4, 33. [CrossRef]

171. Viability and Survival of Free and Encapsulated Probiotic Bacteria in Cheddar Cheese I Western Sydney University ResearchDirect. Available online: https:/ / researchdirect.westernsydney.edu.au/islandora/object/uws\%3A5276 (accessed on 30 July 2021).

172. Homayouni, A.; Azizi, A.; Ehsani, M.R.; Yarmand, M.S.; Razavi, S.H. Effect of microencapsulation and resistant starch on the probiotic survival and sensory properties of synbiotic ice cream. Food Chem. 2008, 111, 50-55. [CrossRef]

173. Mcmaster, L.D.; Kokott, S.A. Micro-encapsulation of Bifidobacterium lactis for incorporation into soft foods. World J. Microbiol. Biotechnol. 2005, 21, 723-728. [CrossRef] 
174. Muthukumarasamy, P.; Holley, R.A. Survival of Escherichia coli O157:H7 in dry fermented sausages containing microencapsulated probiotic lactic acid bacteria. Food Microbiol. 2007, 24, 82-88. [CrossRef] [PubMed]

175. Frakolaki, G.; Giannou, V.; Kekos, D.; Tzia, C. A review of the microencapsulation techniques for the incorporation of probiotic bacteria in functional foods. Crit. Rev. Food Sci. Nutr. 2021, 61, 1515-1536. [CrossRef]

176. Zhao, C.; Zhu, Y.; Kong, B.; Huang, Y. Dual-core prebiotic microcapsule encapsulating probiotics for metabolic syndrome. ACS Appl. Mater. Interfaces 2020, 12, 42586-42594. [CrossRef] [PubMed]

177. Zhang, Y.; Lin, J.; Zhong, Q. The increased viability of probiotic Lactobacillus salivarius NRRL B-30514 encapsulated in emulsions with multiple lipid-protein-pectin layers. Food Res. Int. 2015, 71, 9-15. [CrossRef]

178. Whorwell, P.J.; Morel, J.; Duane, C. Efficacy of an encapsulated probiotic Bifidobacterium infantis 35624 in women with irritable bowel syndrome. Am. J. Gastroenterol. 2006, 101, 1581-1590. [CrossRef]

179. Anselmo, A.C.; Mchugh, K.J.; Webster, J.; Langer, R.; Jaklenec, A. Layer-by-layer encapsulation of probiotics for delivery to the microbiome. Adv. Mater. 2016, 28, 9486-9490. [CrossRef] [PubMed]

180. Zheng, D.-W.; Li, R.-Q.; An, J.-X.; Xie, T.-Q.; Han, Z.-Y.; Xu, R.; Fang, Y.; Zhang, X.-Z. Prebiotics-encapsulated probiotic spores regulate gut microbiota and suppress colon cancer. Adv. Mater. 2020, 32, 2004529. [CrossRef] [PubMed]

181. Solanki, H.K.; Pawar, D.D.; Shah, D.A.; Prajapati, V.D.; Jani, G.K.; Mulla, A.M.; Thakar, P.M. Development of microencapsulation delivery system for long-term preservation of probiotics as biotherapeutics agent. BioMed Res. Int. 2013, 2013, 620719. [CrossRef]

182. Martín, M.J.; Lara-Villoslada, F.; Ruiz, M.A.; Morales, M.E. Microencapsulation of bacteria: A review of different technologies and their impact on the probiotic effects. Innov. Food Sci. Emerg. Technol. 2015, 27, 15-25. [CrossRef]

183. Capela, P.; Hay, T.K.C.; Shah, N.P. Effect of homogenisation on bead size and survival of encapsulated probiotic bacteria. Food Res. Int. 2007, 40, 1261-1269. [CrossRef]

184. Razavi, S.; Janfaza, S.; Tasnim, N.; Gibson, D.L.; Hoorfar, M. Nanomaterial-based encapsulation for controlled gastrointestinal delivery of viable probiotic bacteria. Nanoscale Adv. 2021, 3, 2699-2709. [CrossRef]

185. Darjani, P.; Hosseini Nezhad, M.; Kadkhodaee, R.; Milani, E. Influence of prebiotic and coating materials on morphology and survival of a probiotic strain of Lactobacillus casei exposed to simulated gastrointestinal conditions. LWT Food Sci. Technol. 2016, 73, 162-167. [CrossRef]

186. Anal, A.K.; Singh, H. Recent advances in microencapsulation of probiotics for industrial applications and targeted delivery. Trends Food Sci. Technol. 2007, 18, 240-251. [CrossRef]

187. Tripathi, M.K.; Giri, S.K. Probiotic functional foods: Survival of probiotics during processing and storage. J. Funct. Foods 2014, 9 , 225-241. [CrossRef]

188. ISO 10993-5:2009(en), Biological Evaluation of Medical Devices-Part 5: Tests for In Vitro Cytotoxicity. Available online: https://www.iso.org/obp/ui/\#iso:std:iso:10993:-5:ed-3:v1:en (accessed on 27 June 2021).

189. Singh, P.; Medronho, B.; dos Santos, T.; Nunes-Correia, I.; Granja, P.; Miguel, M.G.; Lindman, B. On the viability, cytotoxicity and stability of probiotic bacteria entrapped in cellulose-based particles. Food Hydrocoll. 2018, 82, 457-465. [CrossRef]

190. Puscaselu, R.G.; Lobiuc, A.; Dimian, M.; Covasa, M. Alginate: From food industry to biomedical applications and management of metabolic disorders. Polymers 2020, 12, 2417. [CrossRef] [PubMed]

191. Lopes, S.; Bueno, L.; De Aguiar Júnior, F.; Finkler, C.L.L. Preparation and characterization of alginate and gelatin microcapsules containing Lactobacillus rhamnosus. An. Acad. Bras. Cienc. 2017, 89, 1601-1613. [CrossRef] [PubMed]

192. Ramos, P.E.; Silva, P.; Alario, M.M.; Pastrana, L.M.; Teixeira, J.A.; Cerqueira, M.A.; Vicente, A.A. Effect of alginate molecular weight and $M / G$ ratio in beads properties foreseeing the protection of probiotics. Food Hydrocoll. 2018, 77, 8-16. [CrossRef]

193. Zhang, Z.; Gu, M.; You, X.; Sela, D.A.; Xiao, H.; Mcclements, D.J. Encapsulation of bifidobacterium in alginate microgels improves viability and targeted gut release. Food Hydrocoll. 2021, 116, 106634. [CrossRef]

194. Sathyabama, S.; Kumar, M.R.; Devi, P.B.; Vijayabharathi, R.; Priyadharisini, V.B. Co-encapsulation of probiotics with prebiotics on alginate matrix and its effect on viability in simulated gastric environment. LWT Food Sci. Technol. 2014, 57, 419-425. [CrossRef]

195. Shi, L.E.; Li, Z.H.; Li, D.T.; Xu, M.; Chen, H.Y.; Zhang, Z.L.; Tang, Z.X. Encapsulation of probiotic lactobacillus bulgaricus in alginate'milk microspheres and evaluation of the survival in simulated gastrointestinal conditions. J. Food Eng. 2013, 117, 99-104. [CrossRef]

196. Martin, M.J.; Lara-Villoslada, F.; Ruiz, M.A.; Morales, M.E. Effect of unmodified starch on viability of alginate-encapsulated Lactobacillus fermentum CECT5716. LWT Food Sci. Technol. 2013, 53, 480-486. [CrossRef]

197. Cheow, W.S.; Kiew, T.Y.; Hadinoto, K. Controlled release of Lactobacillus rhamnosus biofilm probiotics from alginate-locust bean gum microcapsules. Carbohydr. Polym. 2014, 103, 587-595. [CrossRef]

198. Song, H.; Yu, W.; Liu, X.; Ma, X. Improved probiotic viability in stress environments with post-culture of alginate-chitosan microencapsulated low density cells. Carbohydr. Polym. 2014, 108, 10-16. [CrossRef]

199. Kamalian, N.; Mirhosseini, H.; Mustafa, S.; Manap, M.Y.A. Effect of alginate and chitosan on viability and release behavior of Bifidobacterium pseudocatenulatum G4 in simulated gastrointestinal fluid. Carbohydr. Polym. 2014, 111, 700-706. [CrossRef] [PubMed]

200. Cook, M.T.; Tzortzis, G.; Khutoryanskiy, V.V.; Charalampopoulos, D. Layer-by-layer coating of alginate matrices with chitosanalginate for the improved survival and targeted delivery of probiotic bacteria after oral administration. J. Mater. Chem. B 2013, 1, 52-60. [CrossRef] [PubMed] 
201. de Araújo Etchepare, M.; Raddatz, G.C.; de Moraes Flores, É.M.; Zepka, L.Q.; Jacob-Lopes, E.; Barin, J.S.; Ferreira Grosso, C.R.; de Menezes, C.R. Effect of resistant starch and chitosan on survival of Lactobacillus acidophilus microencapsulated with sodium alginate. LWT Food Sci. Technol. 2016, 65, 511-517. [CrossRef]

202. Fareez, I.M.; Lim, S.M.; Mishra, R.K.; Ramasamy, K. Chitosan coated alginate-xanthan gum bead enhanced pH and thermotolerance of Lactobacillus plantarum LAB12. Int. J. Biol. Macromol. 2015, 72, 1419-1428. [CrossRef]

203. Prata, A.S.; Grosso, C.R.F. Production of microparticles with gelatin and chitosan. Carbohydr. Polym. 2015, 116, 292-299. [CrossRef]

204. Morrison, I.D.; Ross, S. Colloidal Dispersions: Suspensions, Emulsions, and Foams; John Wiley\&Sons: Hoboken, NJ, USA, $2002 ;$ p. 616.

205. Kwiecień, I.; Kwiecień, M. Application of polysaccharide-based hydrogels as probiotic delivery systems. Gels $2018,4,47$. [CrossRef] [PubMed]

206. Albadran, H.A.; Monteagudo-Mera, A.; Khutoryanskiy, V.V.; Charalampopoulos, D. Development of chitosan-coated agar-gelatin particles for probiotic delivery and targeted release in the gastrointestinal tract. Appl. Microbiol. Biotechnol. 2020, 104, 5749-5757. [CrossRef]

207. Jia, S.; Zhou, K.; Pan, R.; Wei, J.; Liu, Z.; Xu, Y. Oral immunization of carps with chitosan-alginate microcapsule containing probiotic expressing spring viremia of carp virus (SVCV) G protein provides effective protection against SVCV infection. Fish Shellfish Immunol. 2020, 105, 327-329. [CrossRef]

208. Argin, S.; Kofinas, P.; Lo, Y.M. The cell release kinetics and the swelling behavior of physically crosslinked xanthan-chitosan hydrogels in simulated gastrointestinal conditions. Food Hydrocoll. 2014, 40, 138-144. [CrossRef]

209. Cook, M.T.; Tzortis, G.; Charalampopoulos, D.; Khutoryanskiy, V.V. Production and evaluation of dry alginate-chitosan microcapsules as an enteric delivery vehicle for probiotic bacteria. Biomacromolecules 2011, 12, 2834-2840. [CrossRef] [PubMed]

210. De Prisco, A.; Maresca, D.; Ongeng, D.; Mauriello, G. Microencapsulation by vibrating technology of the probiotic strain Lactobacillus reuteri DSM 17938 to enhance its survival in foods and in gastrointestinal environment. LWT Food Sci. Technol. 2015, 61, 452-462. [CrossRef]

211. Graff, S.; Hussain, S.; Chaumeil, J.-C.; Charrueau, C. Increased intestinal delivery of viable saccharomyces boulardii by encapsulation in microspheres. Pharm. Res. 2008, 25, 1290-1296. [CrossRef] [PubMed]

212. Krasaekoopt, W.; Watcharapoka, S. Effect of addition of inulin and galactooligosaccharide on the survival of microencapsulated probiotics in alginate beads coated with chitosan in simulated digestive system, yogurt and fruit juice. LWT Food Sci. Technol. 2014, 57, 761-766. [CrossRef]

213. Mirtič, J.; Rijavec, T.; Zupančič, Š.; Zvonar Pobirk, A.; Lapanje, A.; Kristl, J. Development of probiotic-loaded microcapsules for local delivery: Physical properties, cell release and growth. Eur. J. Pharm. Sci. 2018, 121, 178-187. [CrossRef]

214. Rodklongtan, A.; La-ongkham, O.; Nitisinprasert, S.; Chitprasert, P. Enhancement of Lactobacillus reuteri KUB-AC5 survival in broiler gastrointestinal tract by microencapsulation with alginate-chitosan semi-interpenetrating polymer networks. J. Appl. Microbiol. 2014, 117, 227-238. [CrossRef]

215. Wu, Q.X.; Xu, X.; Xie, Q.; Tong, W.Y.; Chen, Y. Evaluation of chitosan hydrochloride-alginate as enteric micro-probiotic-carrier with dual protective barriers. Int. J. Biol. Macromol. 2016, 93, 665-671. [CrossRef]

216. Çakmak, H.; Özselek, Y.; Turan, O.Y.; Fıratlıgil, E.; Karbancioğlu-Güler, F. Whey protein isolate edible films incorporated with essential oils: Antimicrobial activity and barrier properties. Polym. Degrad. Stab. 2020, 179, 109285. [CrossRef]

217. Zhang, B.; Liu, Y.; Wang, H.; Liu, W.; Cheong, K.; Teng, B. Characterization of seaweed polysaccharide-based bilayer films containing essential oils with antibacterial activity. LWT Food Sci. Technol. 2021, 150, 111961. [CrossRef]

218. Alfaro-Galarza, O.; López-Villegas, E.O.; Rivero-Perez, N.; Tapia- Maruri, D.; Jiménez-Aparicio, A.R.; Palma-Rodríguez, H.M.; Vargas-Torres, A. Protective effects of the use of taro and rice starch as wall material on the viability of encapsulated Lactobacillus paracasei subsp. Paracasei. LWT Food Sci. Technol. 2020, 117, 108686. [CrossRef]

219. Ashwar, B.A.; Gani, A.; Gani, A.; Shah, A.; Masoodi, F.A. Production of RS4 from rice starch and its utilization as an encapsulating agent for targeted delivery of probiotics. Food Chem. 2018, 239, 287-294. [CrossRef]

220. Dafe, A.; Etemadi, H.; Dilmaghani, A.; Mahdavinia, G.R. Investigation of pectin/starch hydrogel as a carrier for oral delivery of probiotic bacteria. Int. J. Biol. Macromol. 2017, 97, 536-543. [CrossRef]

221. Benavent-Gil, Y.; Rodrigo, D.; Rosell, C.M. Thermal stabilization of probiotics by adsorption onto porous starches. Carbohydr. Polym. 2018, 197, 558-564. [CrossRef]

222. Zanjani, M.A.K.; Ehsani, M.R.; Ghiassi Tarzi, B.; Sharifan, A. Promoting Lactobacillus casei and Bifidobacterium adolescentis survival by microencapsulation with different starches and chitosan and poly L-lysine coatings in ice cream. J. Food Process. Preserv. 2018, 42, e13318. [CrossRef]

223. Lancuški, A.; Aiman, A.A.; Avrahami, R.; Vilensky, R.; Vasilyev, G.; Zussman, E. Design of starch-formate compound fibers as encapsulation platform for biotherapeutics. Carbohydr. Polym. 2017, 158, 68-76. [CrossRef]

224. Reyes, V.; Chotiko, A.; Chouljenko, A.; Sathivel, S. Viability of Lactobacillus acidophilus NRRL B-4495 encapsulated with high maize starch, maltodextrin, and gum arabic. LWT Food Sci. Technol. 2018, 96, 642-647. [CrossRef]

225. Thangrongthong, S.; Puttarat, N.; Ladda, B.; Itthisoponkul, T.; Pinket, W.; Kasemwong, K.; Taweechotipatr, M. Microencapsulation of probiotic Lactobacillus brevis ST-69 producing GABA using alginate supplemented with nanocrystalline starch. Food Sci. Biotechnol. 2020, 29, 1475-1482. [CrossRef] [PubMed] 
226. Sultana, K.; Godward, G.; Reynolds, N.; Arumugaswamy, R.; Peiris, P.; Kailasapathy, K. Encapsulation of probiotic bacteria with alginate-starch and evaluation of survival in simulated gastrointestinal conditions and in yoghurt. Int. J. Food Microbiol. 2000, 62, 47-55. [CrossRef]

227. Zabihollahi, N.; Alizadeh, A.; Almasi, H.; Hanifian, S.; Hamishekar, H. Development and characterization of carboxymethyl cellulose based probiotic nanocomposite film containing cellulose nanofiber and inulin for chicken fillet shelf life extension. Int. J. Biol. Macromol. 2020, 160, 409-417. [CrossRef] [PubMed]

228. Singh, P.; Medronho, B.; Miguel, M.G.; Esquena, J. On the encapsulation and viability of probiotic bacteria in edible carboxymethyl cellulose-gelatin water-in-water emulsions. Food Hydrocoll. 2018, 75, 41-50. [CrossRef]

229. Dafe, A.; Etemadi, H.; Zarredar, H.; Mahdavinia, G.R. Development of novel carboxymethyl cellulose/k-carrageenan blends as an enteric delivery vehicle for probiotic bacteria. Int. J. Biol. Macromol. 2017, 97, 299-307. [CrossRef] [PubMed]

230. Chen, B.; Lin, X.; Lin, X.; Li, W.; Zheng, B.; He, Z. Pectin-microfibrillated cellulose microgel: Effects on survival of lactic acid bacteria in a simulated gastrointestinal tract. Int. J. Biol. Macromol. 2020, 158, 826-836. [CrossRef]

231. Chitprasert, P.; Sudsai, P.; Rodklongtan, A. Aluminum carboxymethyl cellulose-rice bran microcapsules: Enhancing survival of Lactobacillus reuteri KUB-AC5. Carbohydr. Polym. 2012, 90, 78-86. [CrossRef] [PubMed]

232. Singh, P.; Medronho, B.; Alves, L.; da Silva, G.J.; Miguel, M.G.; Lindman, B. Development of carboxymethyl cellulose-chitosan hybrid micro- and macroparticles for encapsulation of probiotic bacteria. Carbohydr. Polym. 2017, 175, 87-95. [CrossRef]

233. Huq, T.; Fraschini, C.; Khan, A.; Riedl, B.; Bouchard, J.; Lacroix, M. Alginate based nanocomposite for microencapsulation of probiotic: Effect of cellulose nanocrystal (CNC) and lecithin. Carbohydr. Polym. 2017, 168, 61-69. [CrossRef] [PubMed]

234. Fareez, I.M.; Lim, S.M.; Zulkefli, N.A.A.; Mishra, R.K.; Ramasamy, K. Cellulose Derivatives Enhanced Stability of AlginateBased Beads Loaded with Lactobacillus plantarum LAB12 against Low pH, High Temperature and Prolonged Storage. Probiotics Antimicrob. Proteins 2017, 10, 543-557. [CrossRef] 